\title{
LIQUIDATED SULPHUR MINE “PIASECZNO” - vol. 2. APPLICATION OF INTEGRATED MEASUREMENT TECHNOLOGIES IN THE INVENTORY OF THE “PIASECZNO” WATER BODY - STATE OF 2020
}

\author{
AGH University of Science and Technology, Kraków, Poland \\ gawalkie@agh.edu.pl
}

Keywords: Sulphur Mine "Piaseczno", hydrographic inventory

\begin{abstract}
Among many inland water bodies, a large group includes water bodies formed as an effect of mining activities. Open-cast mining of common minerals, i.e., sand, gravel, loam, basic minerals such as lignite, sulphur and fossil resins of coniferous trees (amber) leaves many excavations, which spontaneously get filled with precipitation waters, black waters (the ones near the surface) and ground waters (deeper underground), often making new and wonderful elements of local landscape. Till the time of political transformations in Poland, due to low awareness of proper reclamation of post-mining areas, few post-mining excavations that spontaneously filled with water were subdued to comprehensive inventory, surveying and geological documentation, which is a necessary condition for their safe use. Examples of such objects are Bagry and Staw Płaszowski in Kraków (mining of loam (clay), sand and gravel), which have undergone full surveying inventory, including bathymetric surveying, only several decades after the end of mining (Gawałkiewicz R., Maciaszek J., 1999; Gawałkiewicz R., 2017; Gawałkiewicz R., 2018a and Gawałkiewicz R., 2018b), despite being the property of the city of Cracow for many years and functioning as sports and recreational, natural (ecological) and economical (fishing facilities) spots. A worth mentioning body of water is the reservoir "Piaseczno" (the commune of Łoniów, the Sandomierz District), now classified as a part of a group of reservoirs with medium retention and has been created after the opencast exploitation of sulphur ended. Despite many years of reclamation measures (shallowing by washing glass sands to the reservoir) and due to the great risk of danger (local landslides, unstable ground in the costal zones, artificially maintained level of the water table) the Loniów commune did not approve this reservoir to use; and nowadays, the reservoir is not suitable for any form of use. The only function that can be fulfilled is ecological function. In the article the results of the complex geodetic (littoral zone) and hydrographic (body of water) inventory are presented. It was possible owing to the use of the remote-controlled HyDrone produced by Seeflor Systems and equipped with a SonarMite BTX/SPX OHMEX ultrasonic sonar by Lymtech and a GNSS set by Trimble (R8s antenna + TSC3 controller) and biological inventory in the littoral zone. Detailed morphometric parameters of the reservoir were also noted based on the integrated geodetic and bathymetric measurements, which in the future may provide valuable data used in the process of adapting the analyzed area for various socio-economical purposes, while maintaining a high degree of safety of its use.
\end{abstract}




\title{
ZLIKWIDOWANA KOPALNIA SIARKI „PIASECZNO” - cz. 2. ZASTOSOWANIE ZINTEGROWANYCH TECHNOLOGII POMIAROWYCH W INWENTARYZACJI AKWENU „PIASECZNO” - STAN 2020 r.
}

\author{
Słowa kluczowe: Kopalnia Siarki „Piaseczno”, inwentaryzacja hydrograficzna
}

\begin{abstract}
Abstrakt
Spośród licznej grupy śródlądowych zbiorników wodnych dużą grupę stanowią obecnie akweny będące wynikiem działalności górniczej. Eksploatacja odkrywkowa kopalin pospolitych, tj.: piasków, żwirów, gliny, kopalin podstawowych, takich jak węgiel brunatny, surowców chemicznych, jak siarka, oraz kopalnych żywic drzew iglastych (bursztynu) pozostawia po sobie liczną wyrobiska, które z czasem wypełniają się samoistnie wodami opadowymi, zaskórnymi (przypowierzchniowymi) oraz gruntowymi (podziemnymi), tworząc często nowe i niezwykłe elementy lokalnego krajobrazu. Do czasu przemian ustrojowych w Polsce znikoma świadomość właściwej rekultywacji terenów pogórniczych decydowała o tym, iż niewiele wyrobisk poeksploatacyjnych samoistnie wypełnionych wodą doczekało się kompleksowej inwentaryzacji i udokumentowania mierniczo-geologicznego, co jest niezbędnym warunkiem bezpiecznego niegórniczego ich użytkowania. Przykładem takich obiektów wodnych są krakowskie Bagry i Staw Płaszowski (eksploatacja: gliny, piasku, żwiru), które doczekały się pełnej inwentaryzacji geodezyjnej, w tym batymetrycznej, dopiero kilkadziesiąt lat po zakończeniu eksploatacji surowców (Gawałkiewicz R., Maciaszek J., 1999; Gawałkiewicz R., 2017; Gawałkiewicz R., 2018a oraz Gawałkiewicz R., 2018b), mimo iż od wielu lat stanowią własność miasta Krakowa, pełniąc funkcje rekreacyjno-sportowe, przyrodnicze (użytki ekologiczne) oraz gospodarcze (obiekty wędkarskie). Wartym uwagi akwenem wodnym kwalifikowanym obecnie do grupy zbiorników średniej retencji, powstałym po eksploatacji odkrywkowej złóż siarki, jest zbiornik Piaseczno (gm. Łoniów, pow. sandomierski). Pomimo wielu lat rekultywacji (zabezpieczeń zboczy i ich wielokrotnego przemodelowywania, wypłycania poprzez namywanie piasków szklarskich do zbiornika), z uwagi na szereg niebezpieczeństw (lokalnych osuwisk, niestabilnego podłoża w strefach nadbrzeżnych, sztucznie utrzymywanego poziomu zwierciadła wody) nie został przekazany w użytkowanie gminie Łoniów i dziś poza funkcją użytku ekologicznego nie nadaje się do jakiejkolwiek innej formy zagospodarowania. W artykule przedstawiono wyniki kompleksowej inwentaryzacji geodezyjnej (strefa przybrzeżna) i hydrograficznej (akwen) przy wykorzystaniu zdalnie sterowanego hydrodrona HyDrone firmy Seefloor Systems wyposażonego w sondę ultradźwiękową SonarMite BTX/SPX OHMEX firmy Lymtech oraz zestaw GNSS firmy Trimble (antena R8s + kontroler TSC3) oraz inwentaryzacji przyrodniczej w strefie litoralu. Określono także szczegółowe parametry morfometryczne zbiornika na podstawie zintegrowanych pomiarów geodezyjnych oraz batymetrycznych, co w przyszłości może stanowić wartościowy materiał w procesie adaptacji analizowanego terenu do różnych społeczno-gospodarczych celów przy zachowaniu warunku wysokiego stopnia bezpieczeństwa jego użytkowania.
\end{abstract}

\section{INTRODUCTION}

It has been estimated that only about $1 / 3$ of all the Polish water bodies (natural and anthropogenic) have detail bathymetric maps (Choiński A., Ptak M., 2014), despite the fact that they are widely used both in a social and economic way. An important aspect of the qualitative cartographic documentation is continuous updating of materials, which is necessary for the safe use of the water bodies. Nowadays the image of the bottom is automatically obtained from large boats or unmanned small hydrodrones steered from the shore. Sonar technologies efficiently replaced plumb probing, which were work consuming and the quantity and accuracy of the obtained data were highly insufficient in case of deep-water bodies.
The observed nowadays technological progress in surveying is based on the range of solutions, in which handling the instruments or measurement sets is carried out by the radio connection. This refers to technologies applied on the ground (robot total stations), but also in the air (drones) and on the water (hydrodrones). In practice, such solutions are based on wireless communication technology controller - instrument (set), allow us to minimize the number of employees in the team, reducing the costs of field work (economic aspect). Nevertheless, it is more important to increase the safety of the team members (safety aspect), including the operators of measurement instruments in dangerous areas, i.e., industrial or post-industrial zones. A particularly important study area are national water resources. Complex inventory of fluvial and stagnant waters enables us 
to qualitatively and quantitatively analyze waters and their potential. One of basic ranges of the assessment is the contribution of surveying in the measurement of the shoreline and topography of the adjacent area and hydrographic works aiming at making the characteristics of water bodies by determining their morphometric parameters. This makes the base for the classification of the water body and attributing specific functions. So far, the standard way of hydrographic studies on the inland water bodies was to use vessels (boats, yachts, pedalos), which demanded special transport requirements to the study area (tow trucks) and favourable conditions to launch the vessel (ramps or shore with a proper profile). The alternative for the implementation of such method can be independent light vessel equipped in measuring instruments to position the unit (GPS) and measure the depth (supersonic sonar). In Poland such solutions are more and more commonly used in the inventory of natural water bodies (the Hańcza Lake - Popielarczyk D., Templin T., 2014) and anthropogenic water bodies (the reservoir of Brzegi in Kraków - Madusiok D., 2016), including the ones difficult to access (smaller water body in the area of the Bagry reservoir in Kraków, situated within the borders of the ecological utility - Madusiok D., 2019).

The article presents the results of a comprehensive geodetic inventory (littoral zone) and hydrographic inventory (bottom profile) using a remote-control hydrodrone HyDrone by Seefloor Systems equipped with a supersonic sonar SonarMite BTX/SPX OHMEX by Lymtech and a GNSS set by Trimble (aerial R8s + controller TSC3) and nature inventory in the littoral zone of the post-mining excavation Piaseczno (the remains of sulphur mining). The reclamation of the excavation has not been finished, despite geotechnical measures taking place for several years. Due to the plans of bringing back the initial level of the water table to $\sim+146.00 \mathrm{~m}$ a.s.l. (planned increase of the water table ordinate by nearly $8 \mathrm{~m}$ ) and phase nature of the project, this process will require subsequent repetitions to assess the efficiency of the undertaken activities and the degree of geotechnical threats (landslide movements of scarps). The presented in the article the results of comprehensive inventory will make the base for further analyses of topographic changes of the post-mining area and the morphometric changes of the lake bowl in the future. The information contained in part 1 contributes to the history of changes and illustrates the range and large amount of work carried out in sulphur mining in 1971 and glass-sand in 1980 up till now.

\section{ENVIRONMENTAL THREAT AND RECLAMATION WORK IN 2012}

The latest comprehensive inventory of the excavation took place in 2012 (Gawałkiewicz R., 2020), after a tragic landslide of the fragment of the inner ground mass to the water. Earth work was renewed only in 2014, when the littoral scarps were re-modelled alongside almost the whole shoreline, using heavy equipment and the western scarp was secured with the application of the micro-explosion technology.

Due to the need to secure scarps in 2012-2020 in the littoral zones, the southern slope was fortified with geoweb, additionally filled with small stones (fig. 1). These were ad hoc actions covering only the selected fragment of shoreline. The lack of the proper fortifications of scarps, directly adjacent to the water body in the south-eastern and eastern part, at the same time led to small abrasion niches, which was documented by the author in a cartographic work - fig. 10. It can be assumed that further stage of water damming will contribute to the acceleration of the process of geometric destruction of scarps situated in a direct neighbourhood of the water body.

The work of the pump station from the south - eastern side is the condition for the relatively constant level of the water table (safe level), which is very important for preserving stable humidity conditions of the grounds in the area of 5000 ha. Thus, the work of the pumping equipment guarantees safety for the communes and secures the areas from their temporary inundations.

The reclamation works and the work of pumps were financed by the National Fund of the Environmental Protection and Water Management (Polish: Narodowy Fundusz Ochrony Środowiska i Gospodarki Wodnej). The agreement was scheduled to be in power until the end of 2015. On $31^{\text {st }}$ December 2015, the concern who should finance the installation (and maintenance) of pumps after the liquidation of the Sulphur Mine "Machów" (to which the mining excavation "Piaseczno" belongs). The pumps are responsible for regulating the water balance around the excavation. Their failure can cause inundation or flooding of about 5000 ha of orchards in the communes of: Koprzywnica, Łoniów and Samborzec (Staszewski R., 2014). The owners of 

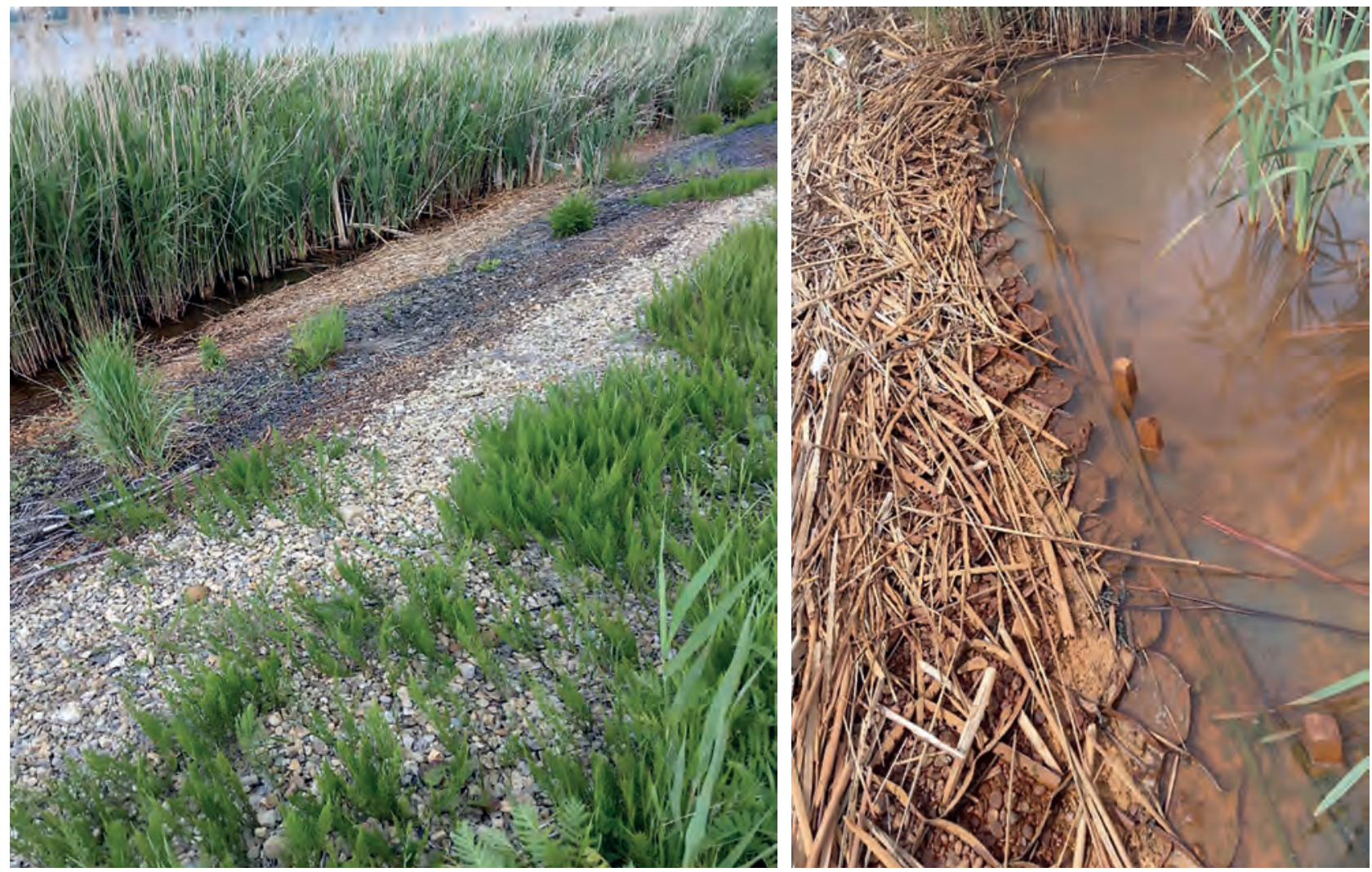

Fig. 1. The example of protecting the southern slopes in the coastal zone, from the water erosion

Rys. 1. Przykład zabezpieczenia zboczy południowych w strefie przybrzeżnej przed erozją wodną

the Sulphur Mine "Machów", i.e., the commune of Tarnobrzeg do not feel responsible for financing the objects and infrastructure on the opposite bank of the Vistula River and yet in another voivodeship. Thus, there is a serious threat of ecological catastrophe if the respective authorities show lack of interest in financing the pumps. Consequently, due to the financial neglect of the pump station, about 1200 orchard farms are threatened by degradation. Moreover, the lack of a proper level of water can pose a serious threat for communication systems in the communes of: Łoniów and Koprzywnica and stability of Vistula embankments in the situation of flood threat.

Another problem after the liquidation of the excavation is the lack of the drainage network, which would spontaneously lead to drying a significant area of land (arable land, orchards, built up areas) and allowed proper direction and channelling the precipitation waters and ground waters (with the moment of restoring primary water balance) directly to the Vistula. This expensive measure, in future, will guarantee the present state of ground humidity, even in case of damming till the assumed level of $\sim+146.00 \mathrm{~m}$ a.s.l. (equalling the ordinate to the level of the Tarnobrzeg Lake on the right bank of the Vistula River).

Today the borrow pit is very picturesque and makes a clear dominant in the landscape of the communes Łoniów and Koprzywnica situated upon the Vistula River - fig. 2.

\section{INVENTORY OF THE POST-MINING WORKINGS WITH THE APPLICATION OF INTEGRATED SURVEYING TECHNOLOGIES}

The set for hydrographical measurements of post-mining reservoir "Piaseczno" is a module system, based on two co-operating components, i.e.:

- hydrographical, including:

- catamaran (Seefloor Systems) of wide profile, preventing from collapsing when waves hit the sides. 
a
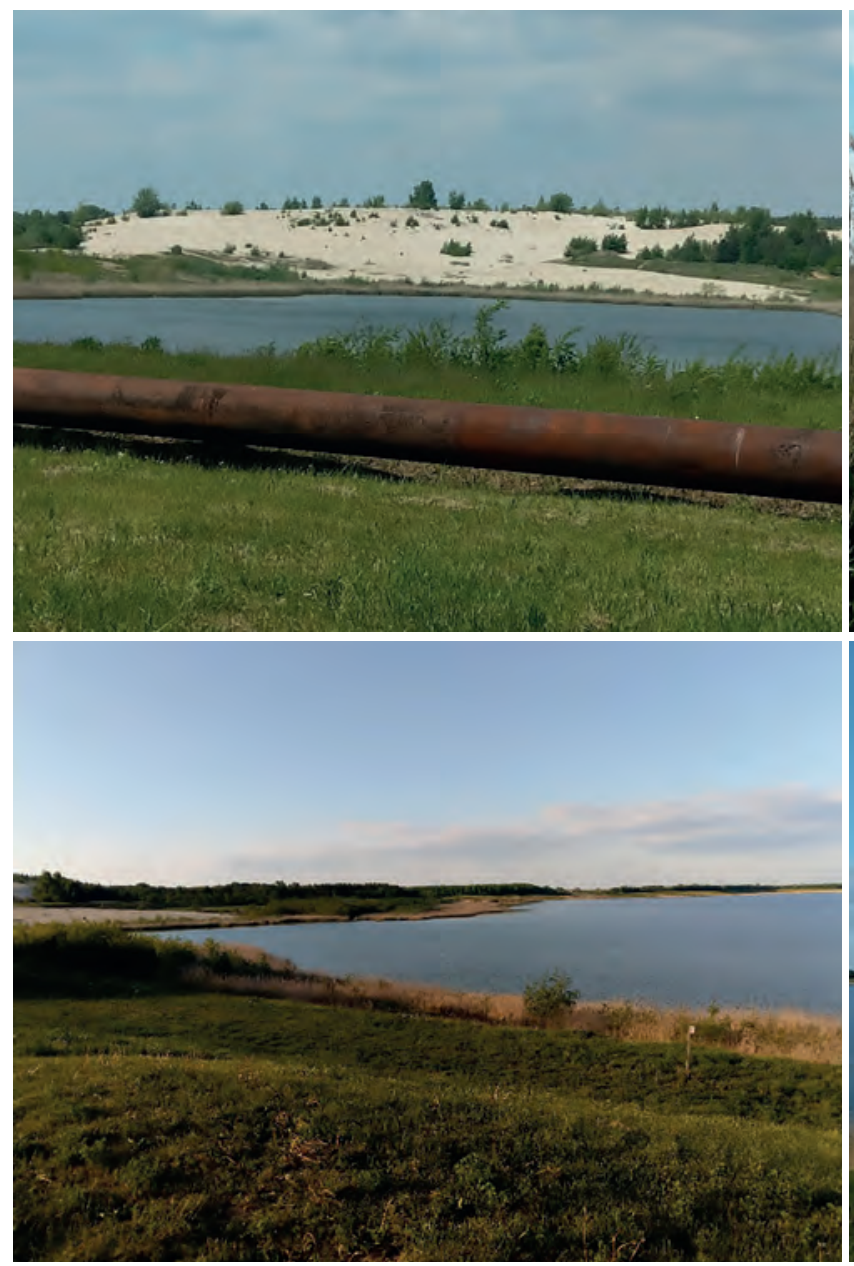

c b
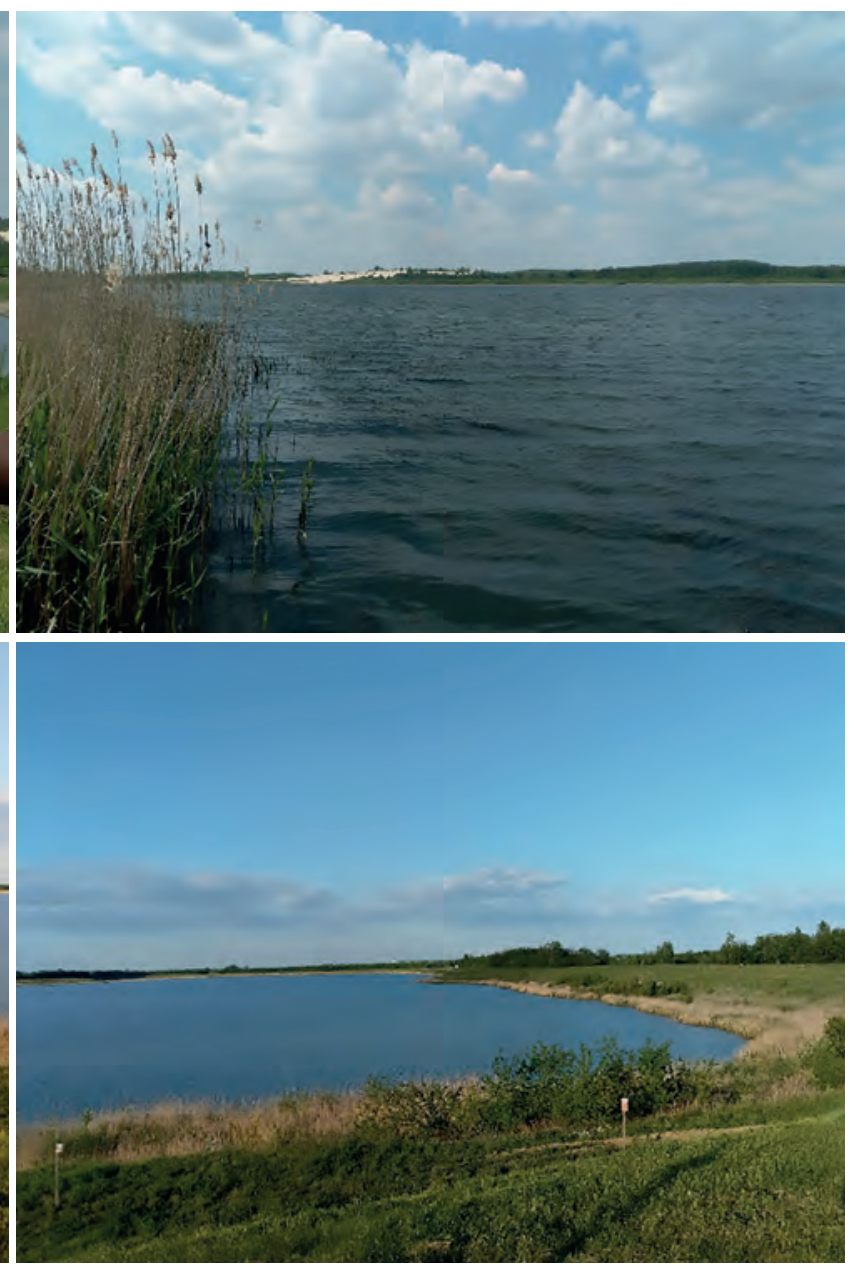

d

Fig. 2. Reclaimed area of the Sulphur Mine "Piaseczno": a - remains of the glass-sand repository in the north-west part of the water body; $\mathrm{b}$ - the view of the lake from the south-east bank; $\mathrm{c}$ - the view of the north and north-west fragment of the water body; $\mathrm{d}$ - the view of the excavation in the south-west part

Rys. 2. Rekultywowany obszar Kopalni Siarki „Piaseczno”: a - pozostałość składowiska piasków szklarskich w części północno-zachodniej zbiornika; b - widok jeziora z południowo-wschodniego brzegu; c - widok północnego i północno-zachodniego fragmentu akwenu; d - widok wyrobiska w części południowo-zachodniej

- echo-sonar consisted of digital (active) "smart" converter P66 equipped in a microprocessor, used to synthesize (filtrate signals from the noise) transmitted frequencies and the interpretation of return signals in the real time (source: Ohmex Instrumentation SonarMite BTX/SPX v5.02 (C) 2016 Lymtech);

- positioning, including:

- GNSS aerial R8s Trimble fixed on a short pole making the carrier of the converter of the echo-sonar OHMEX;
- controller TSC3 Trimble, recording the signals of the positioning of GNSS receiver and their depth defined at the same time by the hydrographical module.

The integration of data obtained from both sets: hydrographical (depth data) and positioning (spatial coordinates of GNNS aerial, the same as the points of the depth measurements) simultaneously, is carried out by the application combining wireless Bluetooth in the memory of GNSS controller TSC3 Trimble. The applied echo-sonar (converter of $235 \mathrm{kHz}$ frequency) 
of focussed narrow beam of ultra-sound impulse $\left( \pm 4^{\circ}\right)$ prevents averaging of the returning signal, guaranteeing high accuracy of the depth with RMSE (Root Mean Square Error) on the level of $\pm 0.025 \mathrm{~m}$. Due to metrological one-beam sonar measurements carried out by Gołuch P., et al. (2010), referring to real accuracy in the conditions of a water body of slight morphological differentiation of the lake bowl, the reference of depth measurements of the instrument to the measurements with a classical plumb and the application of the true error theory, allows accurate assessment of the precision of measurement. They estimated that the mean error of determining the depth in the pelagic zone was $\mathrm{m}_{\mathrm{o}}= \pm 0.11 \mathrm{~m}$, while in littoral zone $\mathrm{m}_{\mathrm{o}}= \pm 0.19 \mathrm{~m}$.

In practice, the accuracy of depth measurement depends on the frequency of the signal converter and the characteristics of the water environment, i.e.: temperature (the influence of the thermocline on the speed of sound in water - Popielarczyk D., Templin T., 2014), the degree of salinity and water turbidity (content of silt and loam particles), the influence of turbulent movements around the converter, caused by the propellers of the vessel (in the presented set the echosonar is situated in front of the propellers), the bottom (hard, silty, covered by water vegetation, etc.). Thus, one can expect the decrease of the accuracy in the littoral zone due to silt and submerged vegetation (the curled pondweed (Potamogeton crispus)) and relatively high accuracy in the pelagic zone in the areas of relatively flat bottom represented by loams or sands.

According to the data (Ohmex Instrumentation SonarMite BTX/SPX v5.02 (C) 2016 Lymtech) for a typical depth $10 \mathrm{~m}$, the measurement error caused by the change of the water characteristic (warm fresh water cold saline water), changes the speed of the sound wave of about $\pm 30 \mathrm{~m} / \mathrm{s})$, can be about $\pm 20 \mathrm{~cm}( \pm 2 \%)$.

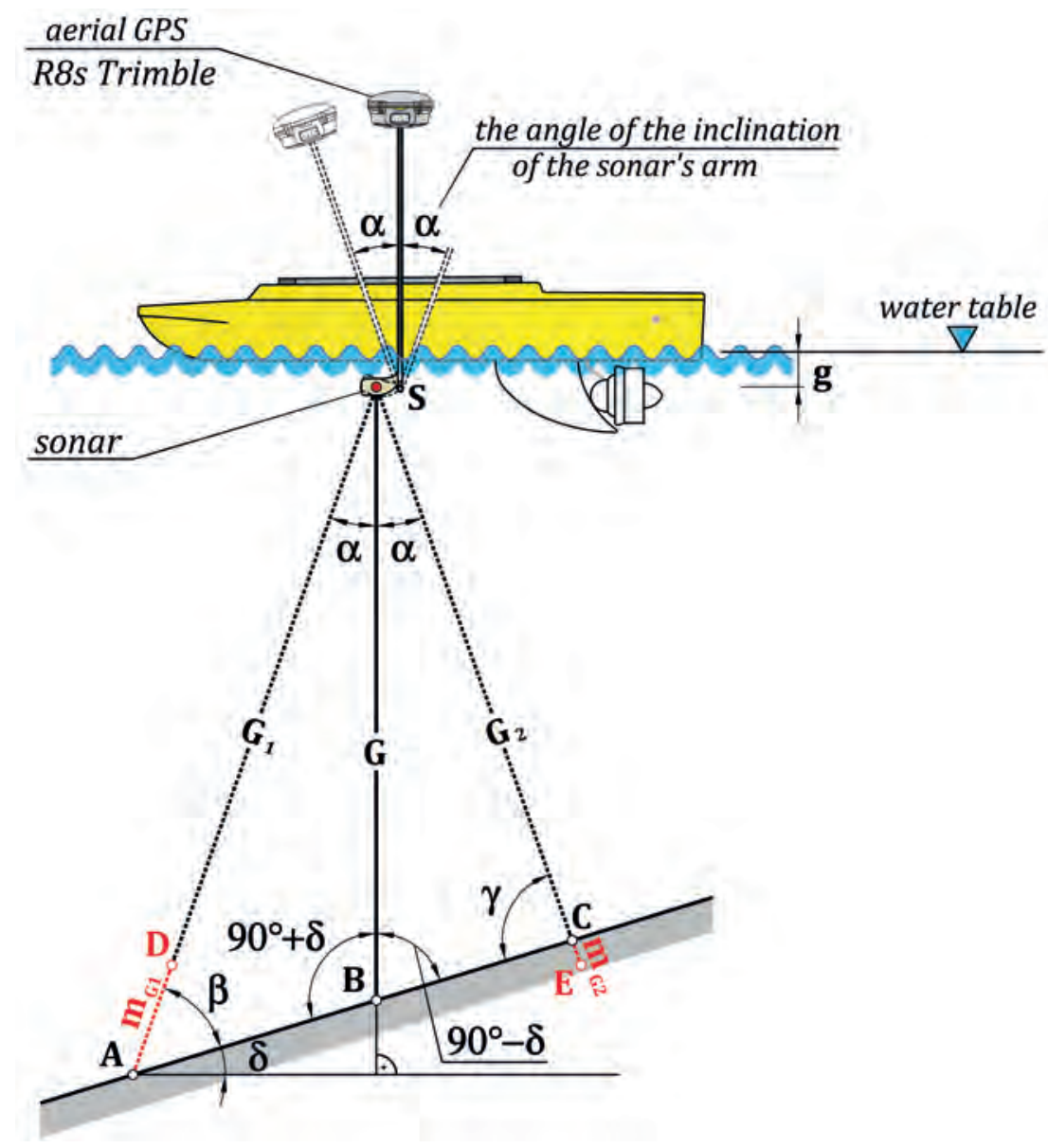

Fig. 3. The impact of the inclination of the echo-sonar's axis on the depth measurement error in the measurement point Rys. 3. Wpływ wychylenia osi echosondy na błąd wyznaczenia głębokości zbiornika w punkcie pomiaru 
Table 1. Basic technical parameters of the portable platform in hydrographical measurements of HyDrone and the auxiliary components

Tabela 1. Zestawienie podstawowych parametrów technicznych przenośnej platformy do pomiarów hydrographicznych HyDrone oraz komponentów towarzyszących

\begin{tabular}{|c|c|c|c|}
\hline & Element & Parameter & Value / Model \\
\hline \multirow{17}{*}{ 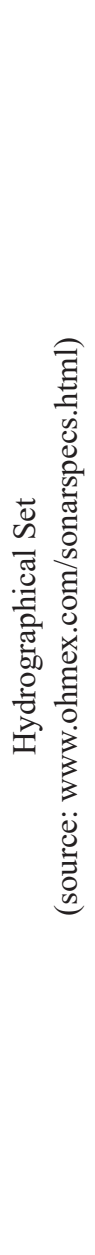 } & \multirow{7}{*}{$\begin{array}{c}\text { Vessel } \\
\text { (Catamaran) }\end{array}$} & Maximal Velocity & $3 \mathrm{~m} / \mathrm{s}(10.8 \mathrm{~km} / \mathrm{h})$ \\
\hline & & Mean Velocity & $1-1.5 \mathrm{~m} / \mathrm{s}(3.6-5.4 \mathrm{~km} / \mathrm{h})$ \\
\hline & & Type of Engine & 2 brushless engines cooled by water \\
\hline & & Empowerment of Engines & $\begin{array}{l}2 \text { batteries } 12 \mathrm{~V} \\
\text { volume } 10000 \mathrm{mAh} \text { each }\end{array}$ \\
\hline & & Vessel Dimension after Folding & $1168 \mathrm{~mm}$ (length) x $736 \mathrm{~mm}$ (width) \\
\hline & & $\frac{\text { Hull's Material }}{\text { Frame }}$ & $\frac{\text { ABS (HDPE) UV-resistant }}{\text { Aluminium, powder coated }}$ \\
\hline & & Weight / Capacity & $14.9 \mathrm{~kg} / 11.3 \mathrm{~kg}$ \\
\hline & \multirow{3}{*}{ Remote Control } & Model / Frequency & Futaba / $2.4 \mathrm{GHz}$ \\
\hline & & Number of Channels & 16 \\
\hline & & Remote Sensing Range R/C & Up to $2 \mathrm{~km}$ \\
\hline & \multirow{7}{*}{$\begin{array}{c}\text { Echo-sonar } \\
\text { [source: OHMEX } \\
\text { INSTRUMENTATION } \\
\text { 2016] }\end{array}$} & $\begin{array}{c}\text { Make of Converter / Type of Converter / } \\
\text { System }\end{array}$ & $\begin{array}{c}\text { OHMEX / P66 / SonarMite } \\
\text { BTX (option with Bluetooth) /SPX }\end{array}$ \\
\hline & & Frequency of the Converter & $235 \mathrm{kHz}$ (active) \\
\hline & & $\begin{array}{c}\text { Type of Echo-sonar / Frequency of the } \\
\text { active system of the converter }\end{array}$ & One-beam / $235 \mathrm{kHz}$ \\
\hline & & Range of depth measurement & $0.3 \div 75 \mathrm{~m}$ \\
\hline & & Accuracy of depth measurement & $\pm 0.025 \mathrm{~m}(\mathrm{RMS})$ \\
\hline & & Angle of focussing the ultra-sound beam & $\pm 4^{\circ}$ \\
\hline & & The range of the speed of the sound ${ }^{(*)}$ & $\begin{array}{c}1400 \div 1600 \mathrm{~m} / \mathrm{s} \\
\text { (default: } 1500 \mathrm{~m} / \mathrm{s})\end{array}$ \\
\hline \multirow{2}{*}{ 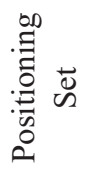 } & \multirow{2}{*}{ GNSS Set } & Aerial GPS (positioning) & R8s Trimble \\
\hline & & Controller (data recorder) & TSC3 Trimble \\
\hline
\end{tabular}

${ }^{(*)}$ - variable value, depending on water, temperature, salinity, turbidity.

The analyzed hydrographical set was designed to carry out studies in small depth, thus does not have a gyroscopic system that could neutralize the influence of the wave-caused movement of a vessel on the stability of the system (keeping the pole with the echo-sonar in a vertical position). According to the author, the final accuracy of the depth measurement is mostly affected by the error resulting from temporary deviation of the converter from the vertical (placed on the catamaran) during the measurement, caused by waves on the surface of the water body, caused by wind, which is approximated by the following formulae (Gawałkiewicz R., 2018): 


$$
m_{G 1(A D)}=G \cdot \frac{\cos \delta}{\cos (\alpha+\delta)}-G
$$

and

$$
m_{G 2(C E)}=G \cdot \frac{\cos \delta}{\cos (\alpha-\delta)}-G
$$

(1) and (2)

where:

$\mathrm{G}$ - real depth in the place of the measurement;

$\mathrm{G}_{1}(\mathrm{SA})$ and $\mathrm{G}_{2}(\mathrm{SC})$ - depths resulting from the deviation of the sonar's axis from the vertical by the angle a;

a - deviation angle of the beam from the vertical (pole inclination);

$\mathrm{d}$ - inclination angle of the bottom in the place of the measurement (marked $\mathrm{x}$ in the figure).

The analyzed system of geometric deformations of the real depth was illustrated in figure 3. Fig. 3 shows that the rapid increase of the error $\mathrm{m}_{\mathrm{G}}$ occurs with the growth of the slope of the examined surface. Assuming the following values: the angle of the bottom slope $\mathrm{d}=36.5^{\circ}$ (place marked as point A in fig. 6), angle of the pole inclination from the echo-sonar on the level $\mathrm{a}=10^{\circ}$ and depth of the water body $\mathrm{H}=32.5 \mathrm{~m}$, the errors of the depth calculated according to formulae (1) and (2) are:
$5.45 \mathrm{~m}$ (error on the level of $16.8 \%$ - towards the slope) and $3.31 \mathrm{~m}$ (error on the level 10.2\% towards the rise). Thus, the condition of minimizing the deformations of the projected area under water, in case of water bodies less than 100 deep is to carry out measurements when the weather is windless, and the course of the vessel is relatively straight without sudden turns and/or sudden corrections of the direction.

Basic technical parameters of the applied hydrographical measurement set are shown in table 1.

The presented in this article measurement set (hydro-drone during its work - fig. 7), allows us to record data with very high density (the smallest time interval 1 second). At the maximal catamaran's speed $(3 \mathrm{~m} / \mathrm{s})$ this allows us to record bathymetric pickets every $3 \mathrm{~m}$. The hydrographical inventory was carried out with the mean velocity of $1-1.5 \mathrm{~m} / \mathrm{s}$, allowing density of $1-1.5 \mathrm{~m}$,

The combination of the positioning of points in space with the use of satellite technology GNSS with bathymetric data determined by one-beam sonar nowadays guarantees precise data in water environment. Used in the positioning of the sonar, GPS receiver (R8s Trimble) due to the correctional data from networks RTN, taken from reference stations VRSnet.pl (service VRS - RTCM 3.1) provides precise co-ordinates, even
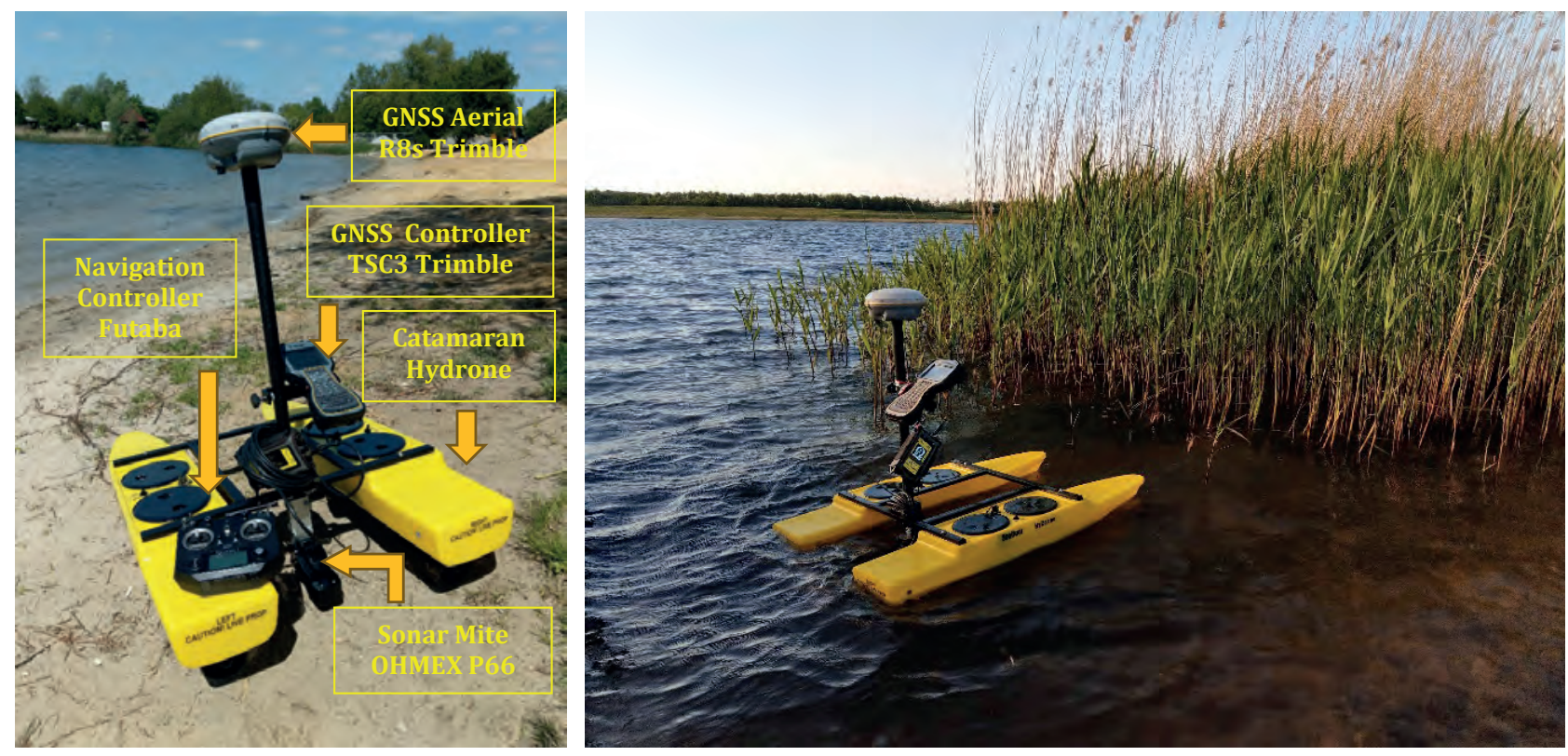

Fig. 4. Measurement set applied in profiling the bottom of the Piaseczno water body (vessel Hydrone Seefloor, echosonar OHMEX - converter P66, positioning of sonar: GNSS receiver R8s Trimble + controller TSC3 Trimble)

Rys. 4. Zestaw pomiarowy wykorzystany do profilowania dna akwenu Piaseczno (jednostka pływająca Hydrone Seefloor, echosonar OHMEX - przetwornik P66, pozycjonowanie sondy: odbiornik GNSS R8s Trimble + kontroler TSC3 Trimble) 
in on-line measurements (accuracy of horizontal positioning is about $\pm 0.03 \mathrm{~m}$, and of vertical position is about $\pm 0.05 \mathrm{~m}$ ). In the applied set, the controller TSC3 Trimble'a made a centre for collecting data from both measurement modules. During the measurements, breaks in the access to the internet were observed. The internet network was responsible for sending the corrections to the GPS observations. The lack of GNSS corrections (significant decrease of the accuracy of positioning) blocks the registration of the position of the receiver in the file, and at the same time, does not allow the depth record obtained from the sonar during the loss of the internet connection by the GNSS set. This means that in the data file there are only complete spatial data of these points, for which it was possible to determine the co-ordinates XYH of GPS aerial and depth $\mathrm{H}$.

\section{DEFINITION OF MORPHOMETRIC PARAMETERS OF THE PIASECZNO RESERVOIR}

The measurement set used in the inventory (fig. 4), allowed us to create a numerous set of the spatial data (altogether 37755 bathymetric pickets). This allowed comprehensive cartographic documentation of the post-mining borrow pit "Piaseczno" (updating of the bathymetric map and the map of the adjacent area of land). Moreover, the registered set of bathymetric measurement data in combination with the measurement pickets of the shoreline, allowed the determination of detail morphometric characteristics of the water body. In practice this is a set of parameters determining the quantitative presentation of the shape of the bowl and the volume of the water.

According to Choiński A., (2008), the parameters characterising any water body are:

- situation of the reservoir defined with geodetic coordinates or geographic coordinates of the gravity centre of the area limited by the shoreline

- the area of the reservoir P;

- the area of the bottom $P_{d n o}$, measured on the slope (calculated from digital models);

- volume of the water mass V;

- ordinate of the water table $\mathrm{H}_{\mathrm{zw}}$ according to the state of the measurement in a defined day;

- maximal depth $\mathrm{G}_{\max }$

- mean depth of the reservoir $\mathrm{G}_{\mathrm{s} r}$, usually calculated as:
- mean for all the pickets in the depth measurement $(* 1$ - table 1$)$;

- ratio of the water body volume and area $(* 2$ table 1);

- mean depth of all the nodes of the numeric model based on the regular GRID - for calculations the network of sides $5 \times 5 \mathrm{~m}$ based on 53747 tetragons of the GRID (*3 - table 1$)$;

- maximal length $\mathrm{L}_{\max }$ (usually represented by the broken line), as the shortest distance between the opposite banks, measured alongside the axis of the reservoir;

- maximal width $\mathrm{S}_{\max }$, the longest section between the opposite banks, measured perpendicularly to the axis of the water body;

- mean width $\mathrm{S}_{\mathrm{sr}}$, usually calculated as:

- ratio of the area of the reservoir and their maximal length $\mathrm{S}_{\mathrm{sr}}=680.6 \mathrm{~m}\left({ }^{* 4}-\right.$ table 1$)$;

- mean of many profiles, perpendicular to the longitudinal of the reservoir (based on 40 profiles, the mean width of the water body is $\mathrm{S}_{\mathrm{sr}}=$ $685.7 \mathrm{~m}\left({ }^{* 5}-\right.$ table 1$)$;

- azimuth of the elongation of the water body;

- length shoreline L;

- depth indicator W defining the shape of the bowl of the reservoir, this is the ratio of the mean depth $\mathrm{G}_{\mathrm{sr}}$ to the maximal depth $\mathrm{G}_{\max }$; the calculations show that this indicator was $\mathrm{W}=0.39$, which qualifies the reservoir to the group of water bodies of a conical bowl, i.e. $W=\sim 1 / 3$;

- shoreline development K (coefficient of the value ranging from 1 to 5), ratio between the length of the shoreline to the circumference of the circle of the area equalling the area of the water body. This parameter is calculated according to the formula (Choiński A., 2008):

$$
K=\frac{L}{2 * \sqrt{\pi * P}}
$$

and equals 1.33 , which means that the shoreline is not very diverse. A similar indicator $\mathrm{K}$ was defined for a post-glacial lake of Wymój, situated in the Olsztyn Lakeland in the commune of Stawiguda, the district of Olsztyn (Grochowska J., Teodorowicz M., 2006).

The calculation of the volume of the water resources makes us assess the accuracy of determining the parameter of volume V. The Polish literature contains many analyses defining the accuracy of determining the 
Table 2. Basic morphometric parameters of the water reservoir Piaseczno, defined based on up-to-date results of the integrated surveying (state for the $24^{\text {th }}$ May 2020)

Tabela 2. Zestawienie podstawowych parametrów morfometrycznych zbiornika wodnego Piaseczno, określonych na podstawie aktualnych wyników zintegrowanych pomiarów geodezyjnych (według stanu na dzień: 24 maja 2020 r.)

\begin{tabular}{|c|c|c|c|c|}
\hline \multicolumn{3}{|c|}{ Morphometric parameter } & $\begin{array}{l}\text { Abbreviation } \\
\text { of the parameter }\end{array}$ & Value of the parameter \\
\hline \multirow{2}{*}{$\begin{array}{l}\text { Location of the } \\
\text { reservoir }\end{array}$} & \multicolumn{2}{|c|}{ Geodetic co-ordinates in system 2000/PL } & $\mathrm{X}_{\mathrm{s}}, \mathrm{Y}_{\mathrm{s}}$ & $5602016.92,7542130.37$ \\
\hline & \multicolumn{2}{|c|}{ Geographic co-ordinates } & $\mathrm{B}, \mathrm{L}$ & $50^{\circ} 33^{\prime} 08.21^{\prime \prime}, 21^{\circ} 35^{\prime} 40.24^{\prime \prime}$ \\
\hline \multicolumn{3}{|c|}{ The area of the reservoir } & $\mathrm{P}$ & $\begin{array}{l}1371452 \mathrm{~m}^{2} \\
137.15 \mathrm{ha}\end{array}$ \\
\hline \multicolumn{3}{|c|}{$\begin{array}{l}\text { The area of the bottom } \\
\text { (based on GRID of } 5 \times 5 \mathrm{~m} \text { ) }\end{array}$} & $P_{\text {dno }}$ & $1422794 \mathrm{~m}^{2}$ \\
\hline \multirow{2}{*}{\multicolumn{2}{|c|}{ Volume of the water mass }} & GRID $5 \times 5 \mathrm{~m}$ & $\mathrm{~V}_{\mathrm{GRID}}$ & $20679639 \mathrm{~m}^{3}$ \\
\hline & & Bathygraphic curve & $\mathrm{V}_{\text {krzywa bat. }}$ & $20027380 \mathrm{~m}^{3}$ \\
\hline \multicolumn{3}{|c|}{$\begin{array}{c}\text { Ordinate of the water table } \\
\text { (measurement GNSS - RTN } 60 \text { seconds) } \\
\text { according to the state on } 24 / 05 / 2020\end{array}$} & $\mathrm{H}_{\mathrm{zw}}$ & $138.11 \mathrm{~m}$ a.s.1. \\
\hline \multicolumn{3}{|c|}{ Minimal ordinate of the bottom } & $\mathrm{H}_{\text {min }}$ & $101.28 \mathrm{~m}$ a.s.1. \\
\hline \multicolumn{3}{|c|}{ Maximal depth of the water body } & $\mathrm{G}_{\max }$ & $-36.83 \mathrm{~m}$ \\
\hline \multicolumn{3}{|c|}{$\begin{array}{l}\text { Mean depth of the reservoir based on } 37755 \text { picket bathymetric } \\
\text { measurements }\end{array}$} & $\mathrm{G}_{\mathrm{sr}}$ & $-14.41 \mathrm{~m}\left(^{* 1}\right)$ \\
\hline \multicolumn{3}{|c|}{ Mean depth of the reservoir calculated from the formula: $G_{s r}=\frac{V}{P}$} & $\mathrm{G}_{\mathrm{sr}}$ & $-14.59 \mathrm{~m}\left({ }^{*}\right)$ \\
\hline \multicolumn{3}{|c|}{ Mean depth of the reservoir based on 53747 nodes of the GRID } & $\mathrm{G}_{\text {sr GRID }}$ & $-14.88 \mathrm{~m}\left({ }^{* 3}\right)$ \\
\hline \multicolumn{3}{|c|}{ Maximal length of the water body $(*)$} & $\mathrm{L}_{\max }$ & $2014.93 \mathrm{~m}$ \\
\hline \multicolumn{3}{|c|}{ Maximal width $(*)$} & $\mathrm{S}_{\max }$ & $1069.20 \mathrm{~m}$ \\
\hline \multicolumn{3}{|c|}{ Mean width of the water body } & $\mathrm{S}_{\text {sr }}$ & $680.6 \mathrm{~m}^{(* 4)} ; 685.7 \mathrm{~m}^{(* 5)}$ \\
\hline \multicolumn{3}{|c|}{ Azimuth of the elongation of the water body } & A & $50^{\circ} 42^{\prime}$ \\
\hline \multicolumn{3}{|c|}{ Length of the shoreline } & $\mathrm{L}$ & $5511 \mathrm{~m}$ \\
\hline \multicolumn{3}{|c|}{ Depth indicator } & W & 0.39 \\
\hline \multicolumn{3}{|c|}{ Indicator of the shoreline development } & $\mathrm{K}$ & 1.33 \\
\hline \multicolumn{3}{|c|}{ Indicator of the elongation of the reservoir } & 1 & 8.1 \\
\hline \multicolumn{3}{|c|}{ Scheme } & & \\
\hline
\end{tabular}

Source: R. Gawałkiewicz - author's own work 
volume of water resources or earth masses $\mathrm{m}_{\mathrm{v}}$ (Maciaszek J., 2008, Wysocki J., Orłowski P., 2012). Selecting a proper algorithm of calculations should be adjusted to the characteristics of the measurement data and the type of the formed spatial model (Gawalkiewicz R., 2018a). Due to uneven character of the distribution of the points (fig. 6), the digital model showing the bowl of the Piaseczno Reservoir was generated in program Surfer by Golden Software using the estimation method of cringing, assuming GRID of $5 \times 5 \mathrm{~m}$.

The characteristic of the model based on a regular network of squares GRID (in 3D - prisms of square or rectangular base), imposes the way of the accuracy assessment. Assuming that the horizontal coordinates of bathymetric pickets, the value of water volume error $m_{V}$ was defined based on the relationship, the selection of the selection of the formula to determine the error of determining volume $\mathrm{m}_{\mathrm{v}}$. Disregarding the error of horizontal coordinates, the value of the error for the volume of waters was defined based on the formula (Borowiecki A., 1994):

$m_{v}= \pm \sqrt{\left(m_{z} \cdot \sqrt{P \cdot P_{o}}\right)^{2}+\left(m_{o} \cdot \sqrt{\frac{P}{4}}\right)^{2}+\left(\frac{1}{2} \cdot \varepsilon_{\max } \cdot P_{o} \cdot \sqrt{n}\right)^{2}}$ where:

$\mathrm{m}_{\mathrm{z}}-$ mean acceptable error of the projection of the area, which was accepted as the mean value of the residue defining the degree of adjusting the GRID model to the distribution of the points of the bathymetric measurement; based on the point set and parameters of 3D GRID, were defined in program Surfer and the value of the projection error was $m_{z}= \pm \mathbf{0 . 1 3 1 m}$;

$\mathrm{P}$ - the area of the reservoir Piaseczno (table 2);

$\mathrm{P}_{\mathrm{o}}-$ the area of a single quadrangle of the GRID $\boldsymbol{P}_{\boldsymbol{o}}$ $=25 m^{2}$

$\mathrm{m}_{\mathrm{o}}-$ mean error of depth measurement, resulting from the specification of the applied ultrasonic sonar $\boldsymbol{m}_{o}= \pm \mathbf{0 . 0 2 5 m}$;

$\mathrm{e}_{\max }-$ the largest distance between the spherical surface and the area of the square, the same as the value of maximal depth, tj. $e_{\max }=36.83 \mathrm{~m}$;

$\mathrm{n}-$ number quadrangles of dimension $5 \times 5 \mathrm{~m}$ filling the reservoir $n=54228$

The formula (2) shows that with the volume of reservoir $\mathrm{V}=20679639 \mathrm{~m}^{3}$, mean volume error is $\mathrm{m}_{\mathrm{V}}= \pm 107210 \mathrm{~m}^{3}$, which makes relative error $\pm 0.52 \%$. The bottom of the excavation has very complex geo-

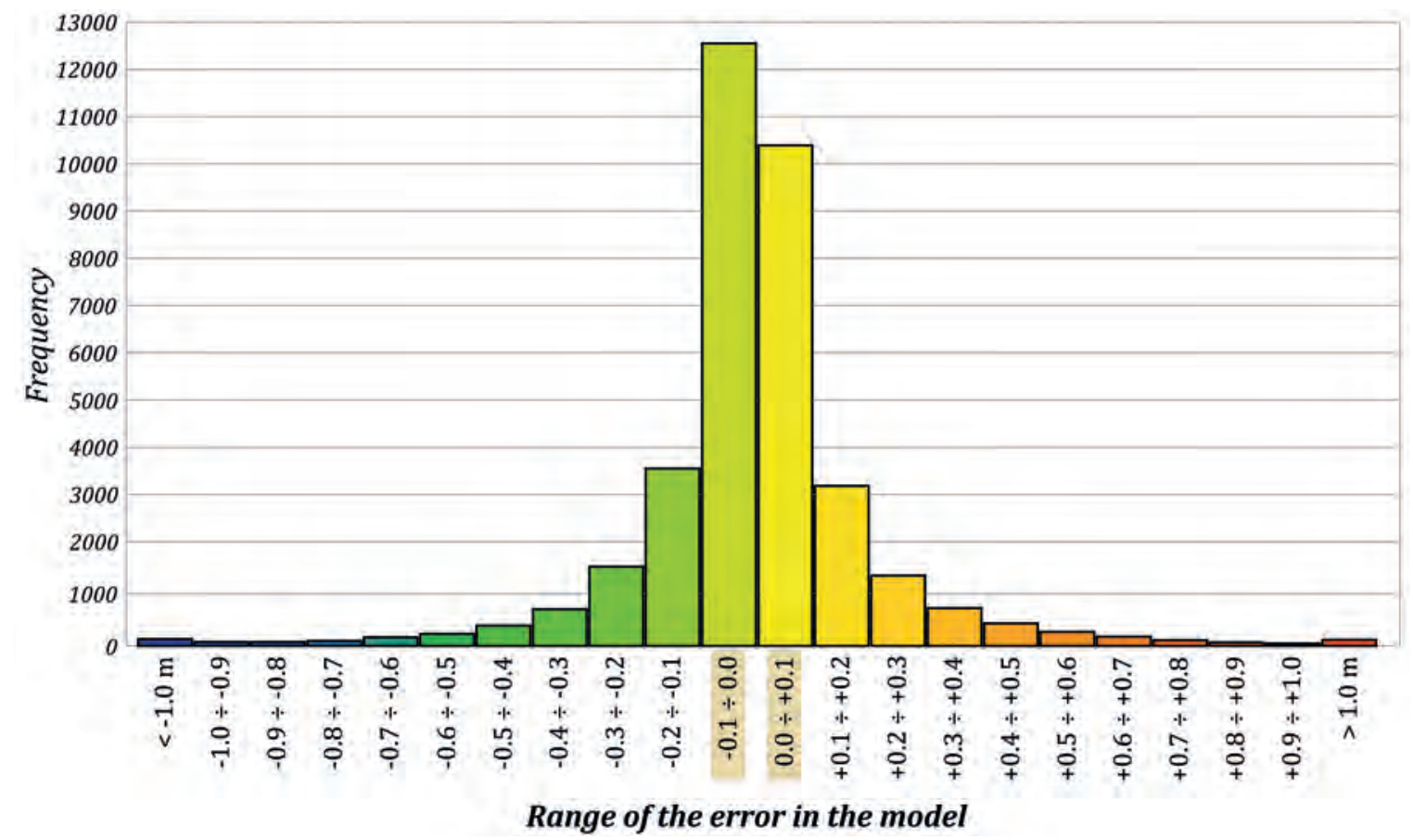

Fig. 5. Histogram of adjustment errors of the model of the bottom (kriging) compared to discrete model (from the measurement) Rys. 5. Histogram błędów dopasowania modelu dna (kriging) do modelu dyskretnego (z pomiaru) 
morphologic structure. The geometry of the surface of the bottom is very diverse and non-linear due to many regulation measures and securing the inner repository with watered grounds (modelling, micro-explosions in the marginal zone of the inner repository) and uncontrolled landslides caused by, among others slow water damming, accumulation of water in the loose ground, especially deposed on the inner repository. Bathymetric measurements are basic tool of recognizing the surface of the bowl and their changes in time. Their description contributes to parametric identification using numeric algorithms. For this article, the model of the bottom was made in the form of GRID of the size of mesh $5 \times 5 \mathrm{~m}$ $(\mathrm{n}=54228)$, where height co-ordinates were determined using algorithm of the method of kriging, where in program Surfer (Golden Software) based on unevenly distributed measurement points (fig. 6). To define the precision of the mathematic model the distribution of residua was applied (height difference between the mathematical model, and the directly measured ordinate of the bottom). For better illustration of the accuracy of the model for differentiated in such a way 3D form, a histogram was made, which illustrates the distribution of error intervals - fig. 5. Among 37755 bathymetric pickets were put, the largest values of residues were registered in zones of significant height

\section{Legenda / Legend:}

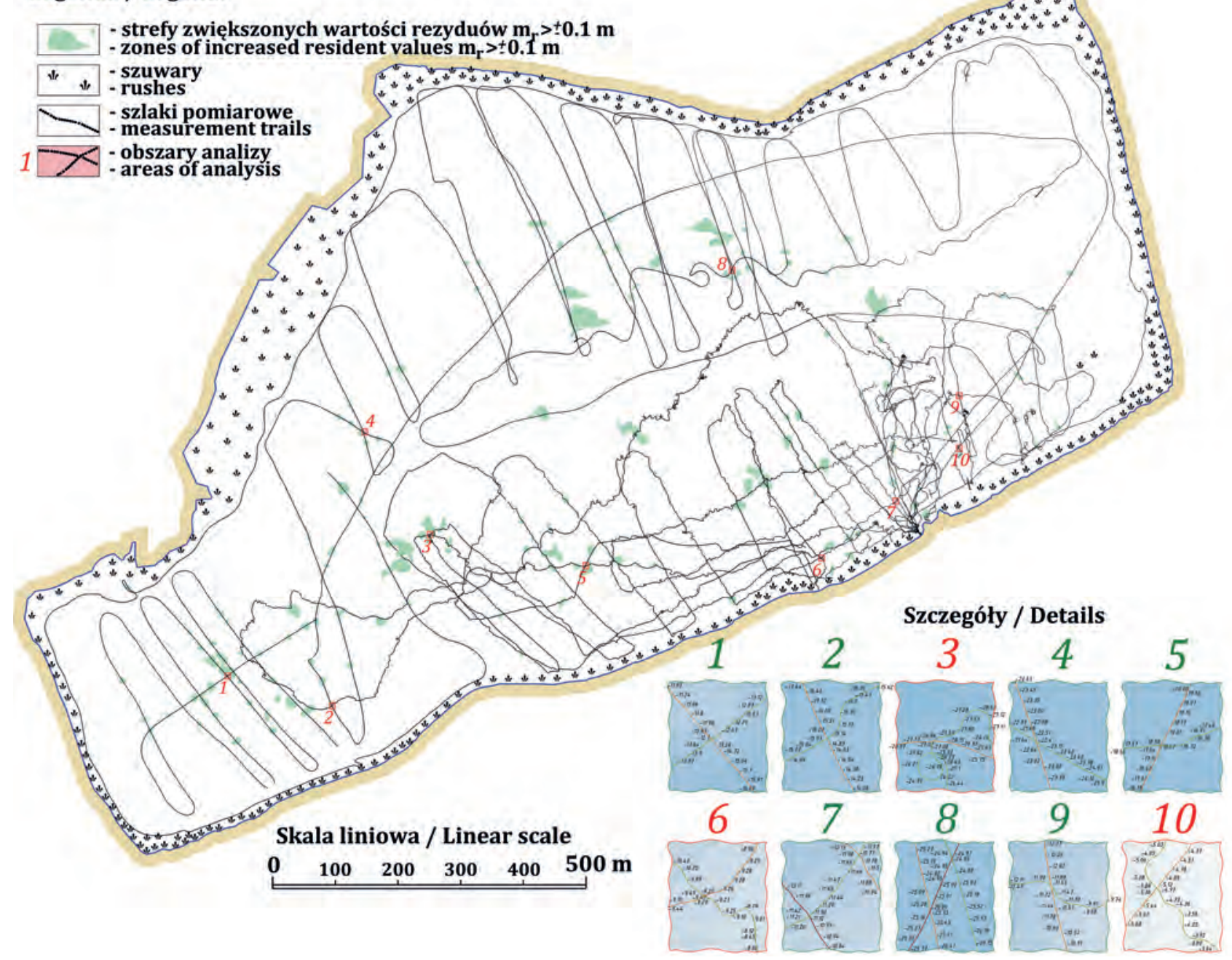

Fig. 6. Location of selected areas of the cover of bottom with pickets: 1-2, 4-5, 7-9-high compatibility of the sonar for crossed trajectories, 3, 6, 10 - influence of a sudden change in the direction of the vessel to the value of depth measurement

Rys. 6. Lokalizacja wybranych obszarów pokrycia dna pikietami: 1-2, 4-5, 7-9-wysoka zgodność wskazań sondy dla przecinających się trajektorii, 3, 6, 10 - wpływ nagłej zmiany kierunku jednostki pływającej na wartość odczytu głębokości. 
changes (angles of the scarps in interval $25^{\circ}-59^{\circ}$ ), as illustrated in fig. 6 .

Another way of presenting the water resources and the characteristics of the bowl is the chart of the bathygraphic curve. The analysis of bathymetric maps of 2005, 2012 (Gawałkiewicz R., 2020), and 2020 allows us to make graphs of three bathygraphic curves (fig. 8), which illustrate the influence of the elevation of the water table on the resources of the retained water, reclamation activities (profiling of scarps, washing out, pushing earth masses to the reservoir) and uncontrolled landslide phenomena, on the character of the changes of the lake bowl. Based on three bathygraphic curves, the water resources were determined in three states. It can be concluded that in 2005 the volume of the water body was $V_{2005}=5604695 \mathrm{~m}^{3}$, in 2012 , due to the water damming and landslide, this value grew to $\mathrm{V}_{2012}=$ $20173840 \mathrm{~m}^{3}$. In 2020 there was a decrease to value $\mathrm{V}_{2020}=20027380 \mathrm{~m}^{3}$. The decrease in the volume in 2012-2020 resulted from the liquidation of the landslide niche in May 2011 by washing into the reservoir earth masses of the inner repository, as well as works connected with profiling scarps in the littoral zone, despite relatively constant level of the water table $( \pm 0.01 \mathrm{~m})$.

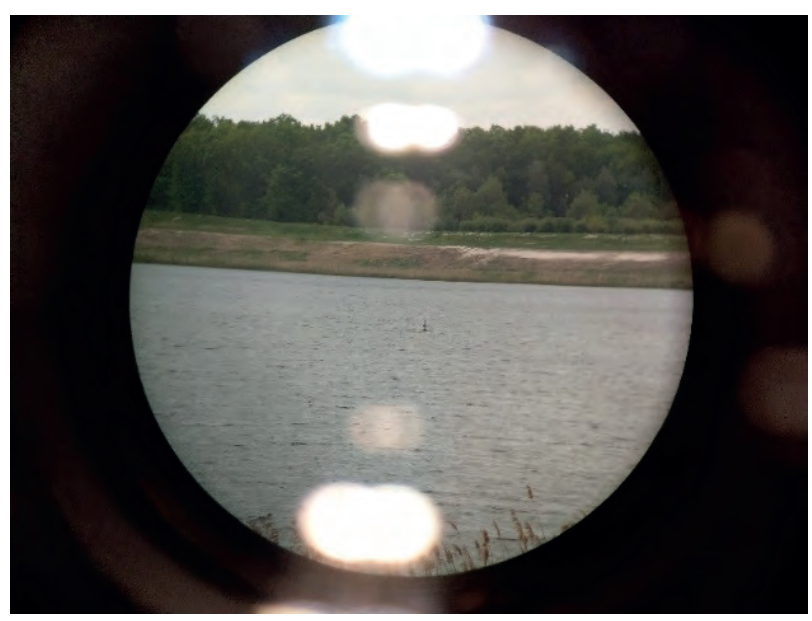

Fig. 7. The view of the hydrodrone during the work on the water body Piaseczno

Rys. 7. Widok hydrodrona podczas pracy na akwenie Piaseczno

Large degree of the biological pollution found in the Baranow sands deposed for years on the top of the inner repository, caused that the process of separation sand and pollutants for the needs of glass industry became unprofitable and the heap became post-industrial waste.

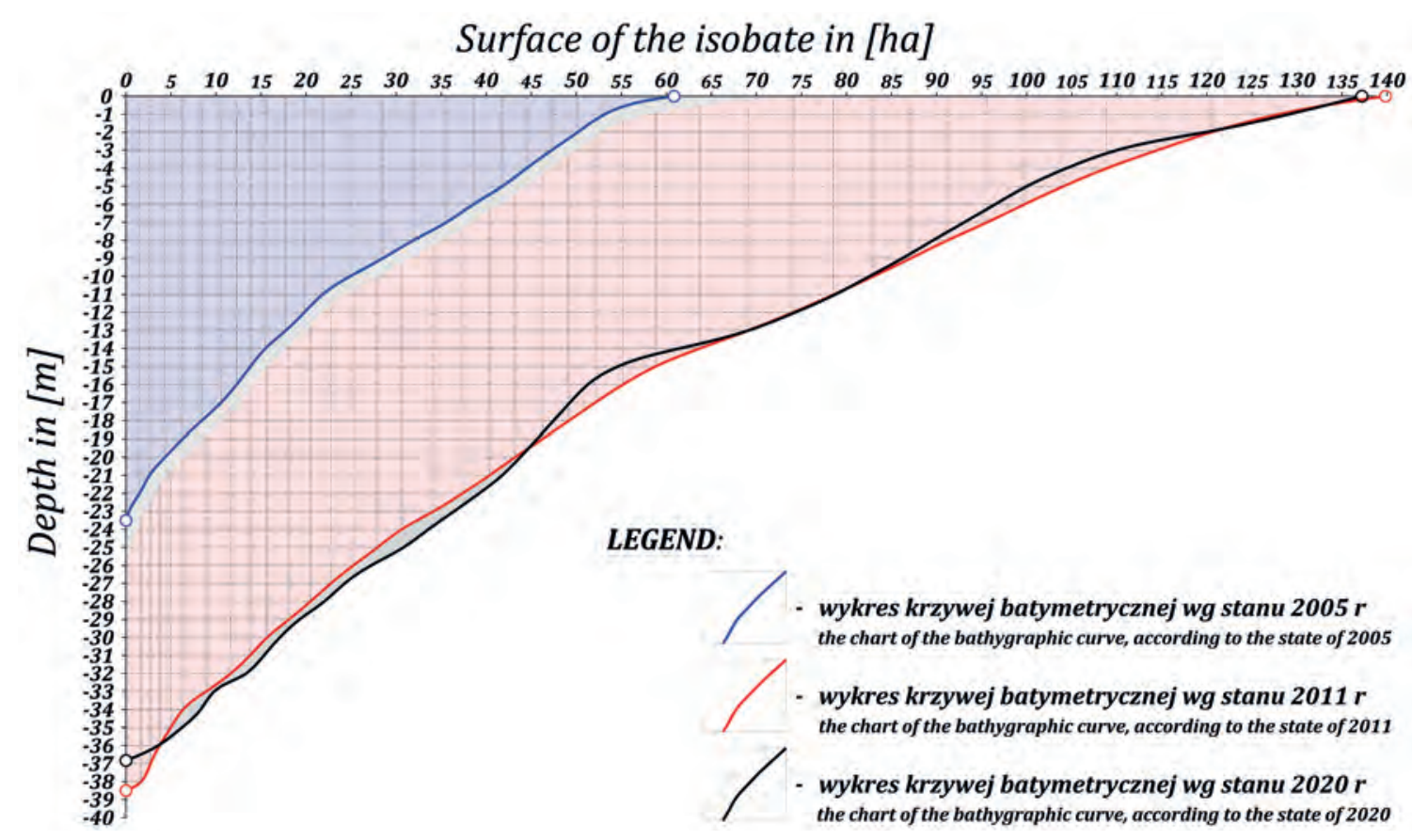

Fig. 8. Graphs of bathygraphic corves of the water body Piaseczno for three states in the geometry of the water body: 2005 $2012-2020$

Rys. 8. Wykresy krzywych batygraphicznych zbiornika Piaseczno dla trzech stanów geometrii zbiornika: 2005 - 2012 - 2020 r. 
A part of the sand heap was destroyed by the landslide of $11^{\text {th }}$ May 2011, and after 2012 in the process of bringing back the utility value, a large part of sand heap, located in the north-west of the reservoir was pushed into the water body (in the washing process). The other part of the repository remained, and now the sand heap makes a clear culmination and a characteristic element of this landscape.

Moreover, mutual relationships between graphs of 2012 and 2020 show the characteristic changes of geometric changes of the bowl of reservoir caused by human activities (reclamation works) and nature (landslides, abrasion) manifested in, among others, in: shallowing of reservoir, changes in the area of the water body (keeping constant level of the water table) and the proportion between the areas of subsequent isobates.

Updating existing bathymetric maps of water bodies and the cartographic content covering the areas directly adjacent to them based on detail geodetic and bathymetric measurements, provides valuable information illustrating the course of all the processes determining the character, size, and directions of geometric evolution of the bowl and littoral scarps, taking place with time due to the forces of nature (landslides) and human activities (forming scarps, alluviation). Presented in fig. 11 profiles of the bowl of the reservoir and the belt of the adjacent area, allow us to track the history of the changes in the geometry of slopes. This evolution results not only from the intended activities of teams implementing the plans of re-modelling scarps and shelves of the excavation, but first of all hydrological conditions (infiltration of water to the rock mass and dampness anisotropic poorly compacted grounds), which can cause uncontrolled mass movements, which took place on $11^{\text {th }}$ May 2011 in the north-western part (Flisiak J., 2014). Longer time of the inundation of the excavation and slow water damming (fig. 9) negatively impacts stability of slopes forming the bowl of the reservoir. Raising the water table in time (switching off the pumps of the drainage system) often contributes to unfavourable reshaping the profile of the slopes, which was illustrated on several profiles based on data of 2005, 2012 and 2020 - fig. 11. The author's paper of 2020 also documented the abrasion zone, resulting from waving. Especially in the unprotected eastern, south-eastern and southern part the effects of natural forces are visible. The limitation of the destructive influence of waves removing earth masses at the base of scarps in the littoral zone, can be achieved by shortening the time of damming.

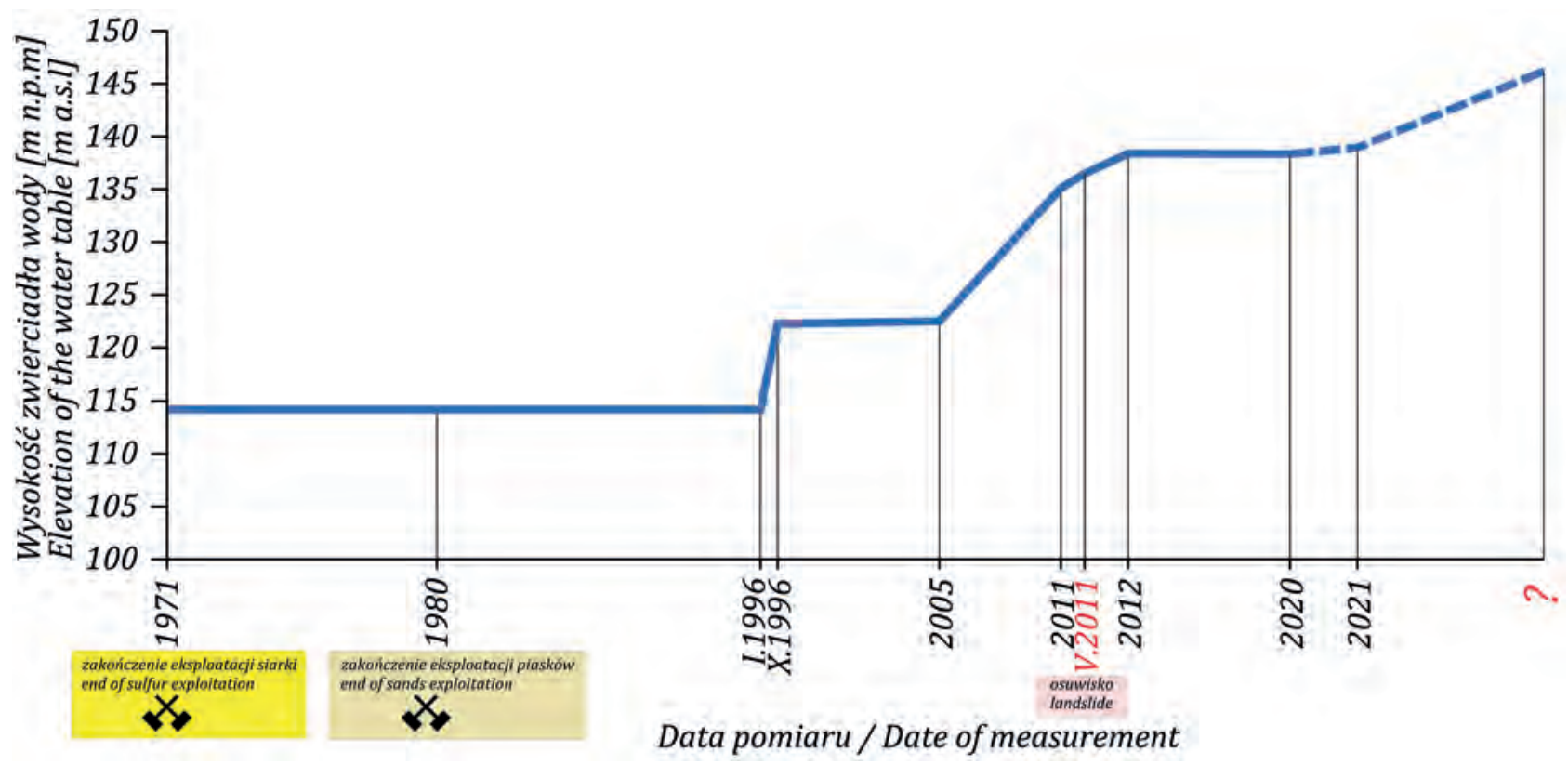

Fig. 9. Graphs of the changes in the ordinate of the water table in time in the excavation of Piaseczno (after 2020 the increase to the level $+139.0 \mathrm{~m}$ a.s.1., and eventually - up to $\sim 146.0 \mathrm{~m}$ a.s.1.)

Rys. 9. Wykresy zmian rzędnej zwierciadła wody w czasie w wyrobisku Piaseczno (po 2020 roku planowany jest wzrost do poziomu +139.0 m n.p.m., a docelowo do +146.0 m n.p.m.) 


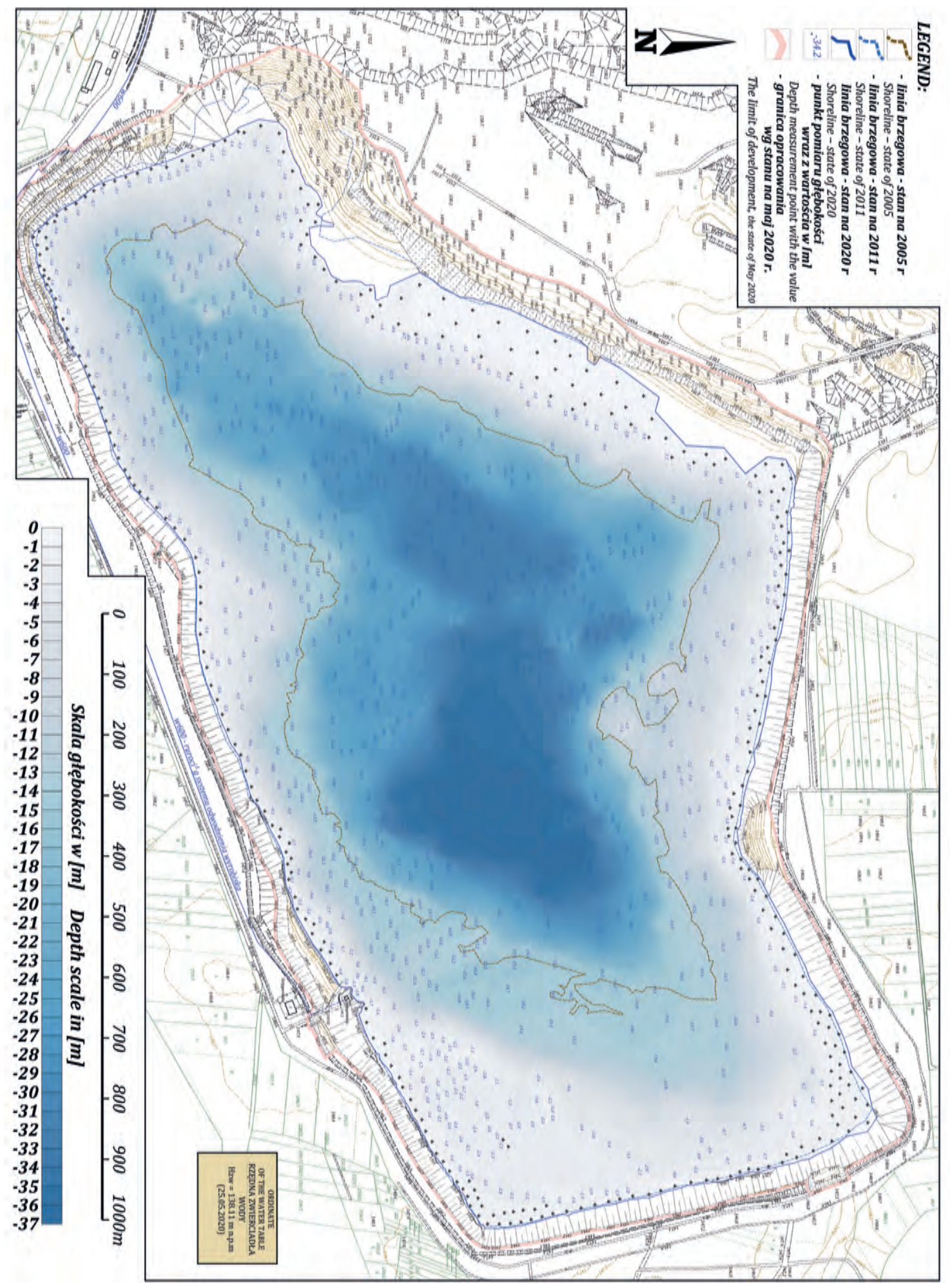

Fig. 10. The situation-altitude map of the mining excavation of the Sulphur Mine "Piaseczno" with the bathygraphic part - according to the state of May 2020 (based on the author's own measurements)

Rys. 10. Mapa sytuacyjno-wysokościowa wyrobiska pogórniczego Kopalni Siarki „Piaseczno” wraz z częścią batygraficzną według stanu na maj 2020 roku (opracowanie na podstawie własnych pomiarów) 

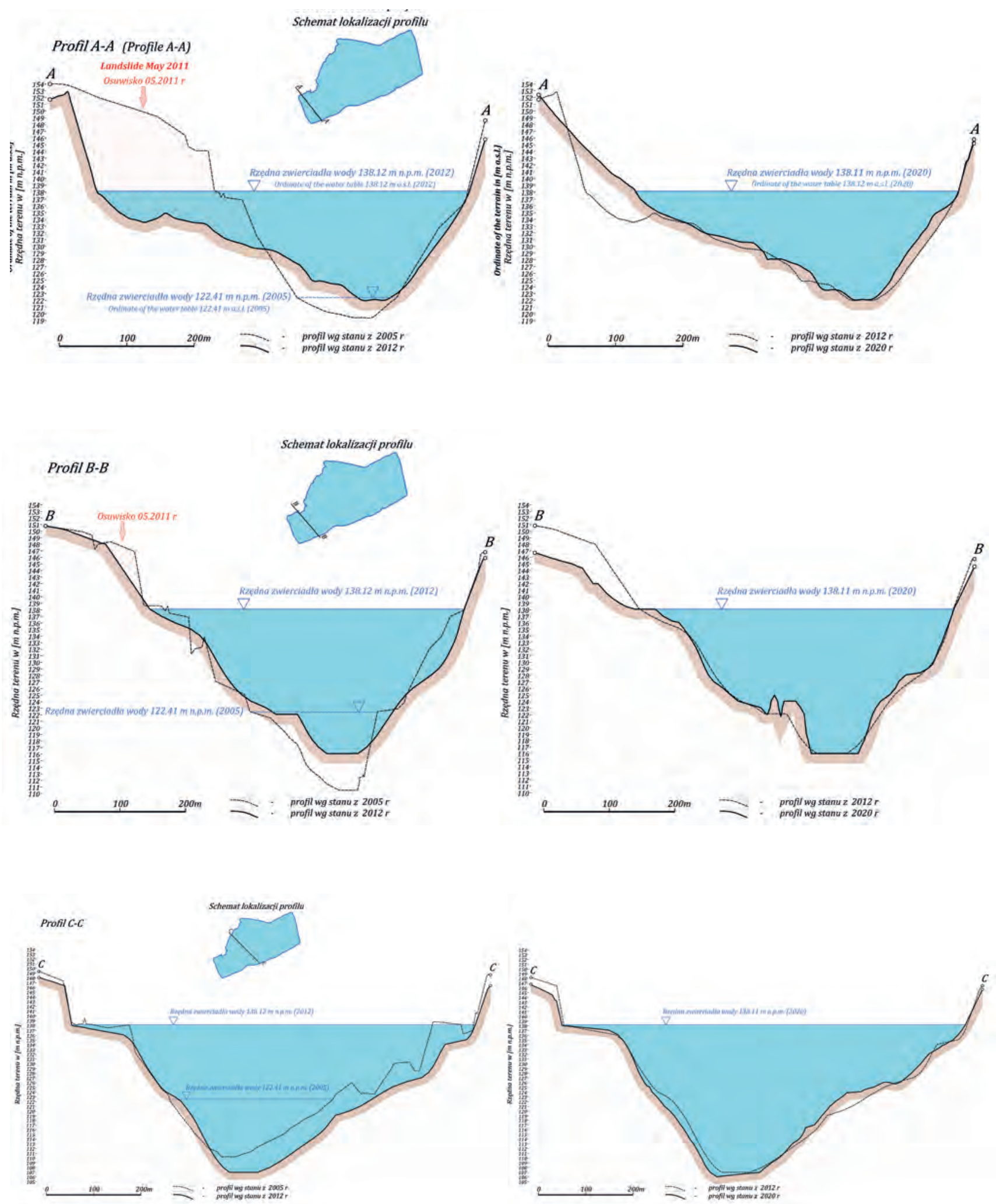

Fig. 11. Selected profiles through the excavation, according to the state of 2005, 2012 and 2020

Rys. 11. Wybrane profile przez wyrobisko według stanów na 2005, 2012 i 2020 r. 

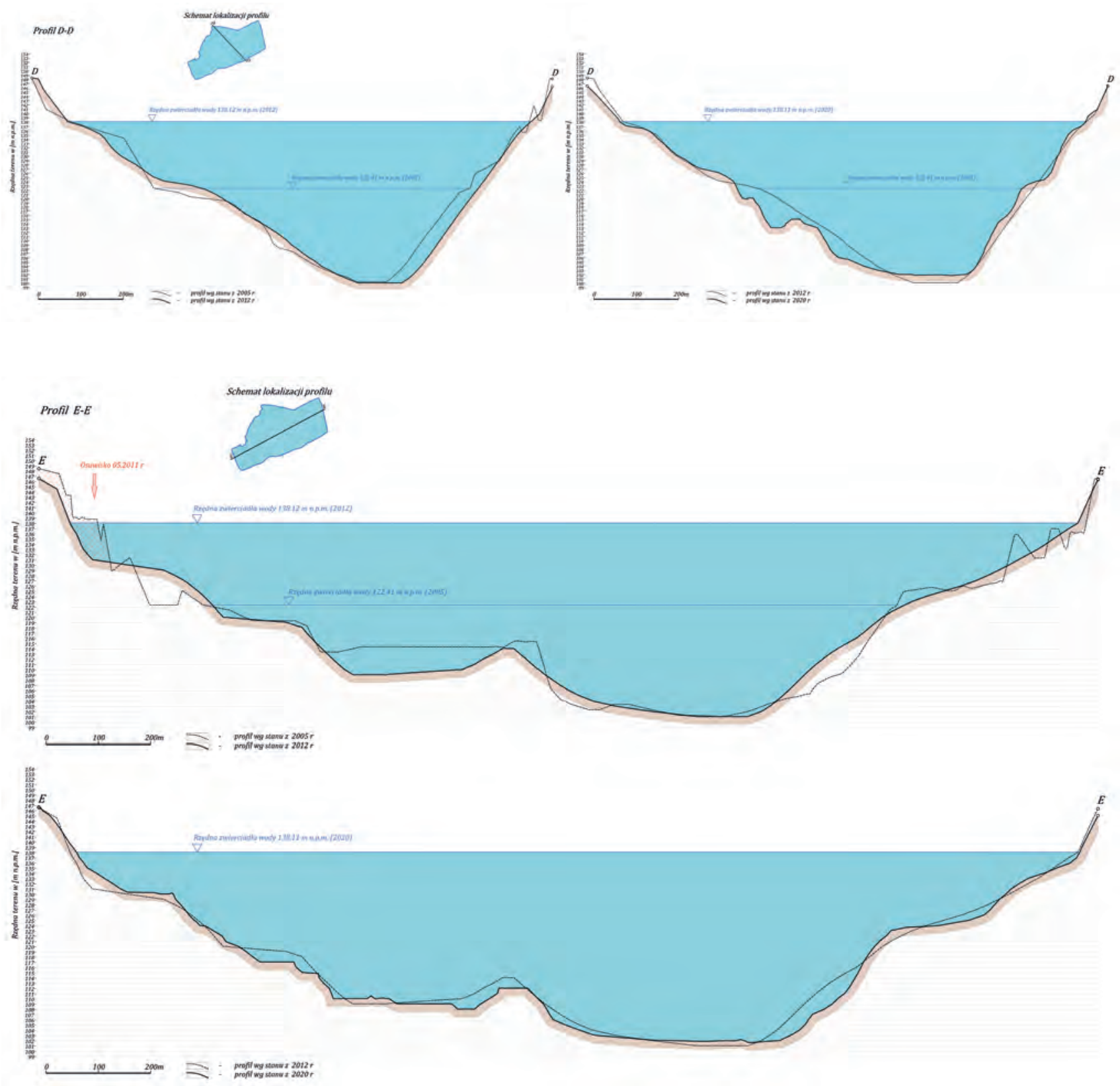

Fig. 11 cont. / Rys. 11 cd.

\section{THE MODEL OF THE RESERVOIR}

Apart from a traditional form of presentation of spatial data in the form of the combined contents of the situation-altitude map of the part above the water and the bathymetric map of the part under water in fig. 10, the development of information techniques in the area of numerical cartography popularized a completely new format of their presentation. The application of popular interpolation algorithms (kriging or triangulation method with linear interpolation) in many available in the market programs of 3D modelling, today provide wide opportunities for the visualization, regardless the applied measurement techniques (total stations, airborne laser scanning (ALS), terrestrial laser scanning TLS, measurements GNSS RTK/RTN, bathymetric measure- 


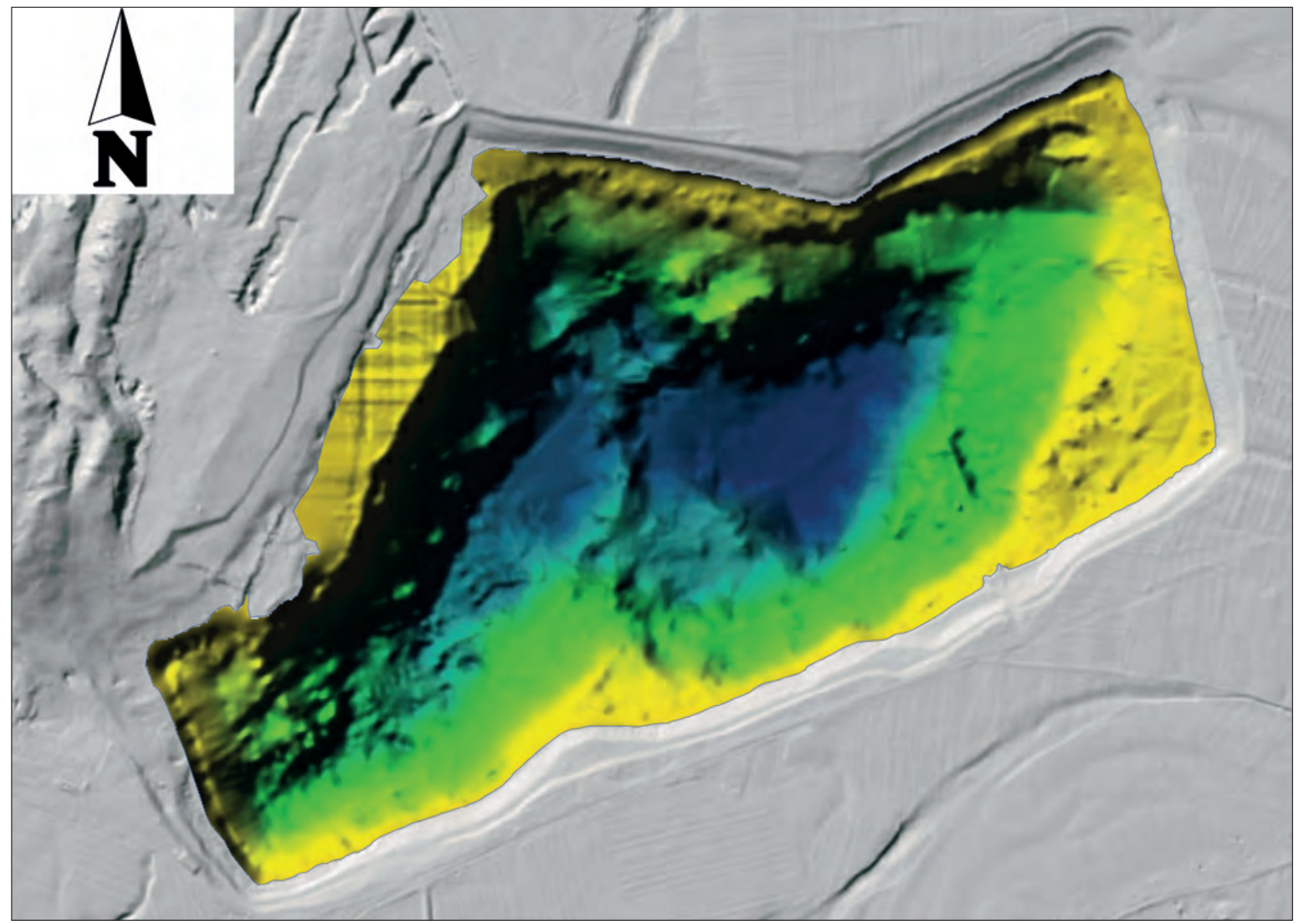

Fig. 12. The 3D model of the water body Piaseczno on the background of the LIDAR model Rys. 12. Model trójwymiarowy zbiornika wodnego Piaseczno na tle modelu LIDAR

ments). The possibility of combining various techniques of the inventory of spatial data facilitates 3D images of the geomorphology of the Earth surface of a part of it. The combination of bathymetric measurements and ALS measurements in program Surfer by Golden Software, allowed us to construct a full image of the morphology of the analysed area of the Piaseczno excavation. The result of the study was presented in fig. 12 .

\section{THE FLORA OF THE POST-MINING RESERVOIR PIASECZNO - STATE OF 2020}

The succession of vegetation in the area changed by anthropogenic influence is a process, that takes place always when human intervention into the environment is significant (Olszewski P., Łączny M., 2010). According to Choiński A. and Ptak M., (2014) the course and speed of the processes and phenomena taking place in water bodies depends on many co-existing and affecting one another factors such as:

- climate (global scale approach);

- catchment and its properties (in a local scale);

- morphometry of the lake bowl (individual approach).

Thus, the element supplementing bathygraphic studies was the analysis of the flora of the reclaimed post-mining reservoir Piaseczno, which in future, combined with the bottom model can play a significant role in choosing proper directions in the management of the reservoir (or its part) and its surrounding. The flora species (macrophytes) are one of basic indicators of the quality assessment of the aquatic environment (in the framework of the assessment of the ecological state of the 
water body based on the Ecological State Macrophyte Index (ESMI), which according to the Directive 2000/60/ WE called the Water Framework Directive [5], makes important element of the water monitoring in Poland.

\section{THE CURLED PONDWEED (Potamogeton crispus)}

In the zones where the reservoir is shallower, especially in its north-eastern and northern part (where shooting was carried out to stabilize earth masses of the inner repository) spontaneous (natural) succession of aquatic vegetation characteristic for stagnant waters took place. The dominating species in the littoral zone is the curled pondweed (Potamogeton crispus) (a perennial plant of Potamogetonaceae family), which is quite a common hydrophyte on the Polish lowlands. It can perfectly adapt to (Szoszkiewicz K et al., 2010):

- mesotrophic reservoirs of moderate fertility of water resulting from little amount of that that the content of nutrients is small in water);

- eutrophic reservoirs, where large concentration of nutrients in water occurs, the development of biological life at the same time the amount of oxygen in water and the limitation of the mineralization processes.
This plant is deeply rooted in the ground (clay, mineral ground, mineral-organic and organic ground). The flowering time is between May and September, which is visible in the form of spike-type inflorescence emerging from water. The curled pondweed has long $(1.5 \mathrm{~m})$ stems with leaves up to $10 \mathrm{~cm}$ long of alternate leaf arrangement (fig. 13). The stems, during the vegetation period are upright and make shelter for the fry. Large density macrophytes in the habitat in the whole water column (from the bottom to the water table), seriously limits sports and recreation function of the water body, but also makes obstacle for vessels with propellers (macrophytes get into propellers and block them) of small power (electric engines of small boats, including hydrodrones).

In fact, the habitats with curled pondweed occur till the depth of 3 metres (Szoszkiewicz K. et al., 2010). Moreover, during late summer the submerged leaves tend to be shed from the stems, which, due to the large mass of plants generates huge amount of bio-waste, which, falling to the bottom stimulate decomposition processes and the formation of sapropel, which causes slow shallowing of the reservoir (Cieśliński R., et al. 2015). Such dense submerged vegetation also significantly limits transparency of water.

According to Bajkiewicz-Grabowska E. (2008), the evolution of water bodies causes spontaneous and
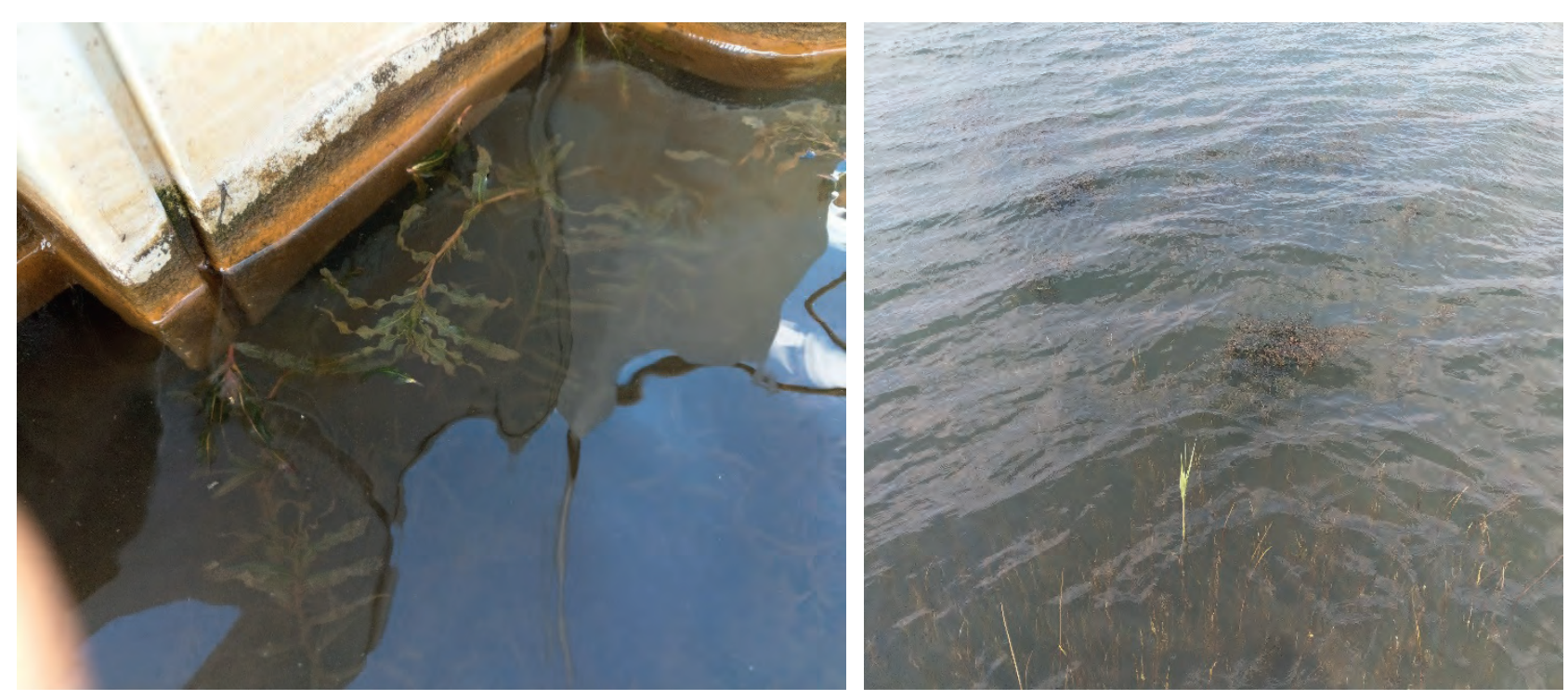

Fig. 13. The curled pondweed (Potamogeton crispus) in the waters of the post-mining borrow pit from the Sulphur Mine "Piaseczno" (littoral zone)

Rys. 13. Rdestnica kędzierzawa (Potamogeton crispus) w wodach wyrobiska pogórniczego Kopalni Siarki „Piaseczno” (strefa przybrzeżna) 
natural transformation of mesotrophic lakes into eutrophic ones. Mesotrophic character of the water body can be recognized when characteristic curled leaves of the curled pondweed are seen, indicating that the water has small amount of nutrients. A littoral zone containing only few species (curled pondweed, common reed, as well as narrowleaf and broadleaf cattail) indicates the eutrophic character of the lake.

\section{COMMON REED (Phragmites australis) AND BROADLEAF CATTAIL (Typha latifolia)}

The littoral zone, apart from Nymphaea-like plants (water plants with roots in the ground and leaves floating on the water) is overgrown by the reed rush (common reed [Phragmites australis] and broadleaf cattail [Typha latifolia]) which, over several recent years, have overgrown shallow zones of the lake alongside almost the whole shore. The existing reed rush is also responsible for silting, which results in shallowing the trough where the rush occurs. A characteristic feature of the reed rush is quick and spontaneous development of the vegetation towards the depth. This is typical vegetation of shallow stagnant waters to the depth of $1.5-1.7 \mathrm{~m}$ of mineral fine grain ground (sand) with high amount of peat, which develops in relatively fertile ground, although it can also be found in habitats with low content of nutrients.

\section{SUMMARY}

The Piaseczno post-mining pit is an example of a post-mining area with a very complicated geological structure and complex hydrological conditions, which resulted in a very long and work-consuming reclamation process. Difficulties are caused by the earth masses deposited within the internal excavation. Earth masses, when exposed to surface water and groundwater, constitute unstable structures in the western and north-western part (2011 landslide) posing a potential threat to future users. This means that the target land development in accordance with the plan and its use must be postponed, despite favourable spatial location, favourable geometric and morphological form and varied depth of the water reservoir, which predisposes the facility to the role of a multi-purpose reservoir.

Modern measurement techniques currently used in land surveying (laser scanners, robotic total stations,
GPS receivers) and water surveying (hydrodrons equipped with acoustic sonars) allow safe remote research (including inventory) far from the sources of danger. The applied measurement set allowed us to collect a large set of bathymetric data, which made it possible to prepare an accurate geomorphological model of the bottom in the Piaseczno reservoir (base model). The density and high accuracy of the spatial data constructing the model can be a valuable comparative material for the final geological survey prepared upon completion of reclamation (modelling and protection of slopes, restoration of the natural water table to the value of $\sim+146.00 \mathrm{~m}$ above sea level). All earthworks carried out until the end of mining activities (including the maintenance of the pumping station) and the planned restoration of the original water table (complete liquidation of the depression funnel) may result in a number of uncontrolled phenomena (movements of earth masses) within the boundaries of the excavation. Their inventory and construction of a new model will allow us to determine the impact of these activities and processes on the final spatial form of the study area in the future, both above and under the water.

The applied measurement set (hydrodrone equipped with a single-beam ultrasonic sonar and GNSS receiver) is characterized by:

- high repeatability of indications in the case of crossing measurement routes, even in the case of measuring zones with large slopes;

- recording of GPS data of the ultrasonic sonar positioning and depth in the memory of the TSC3 controller (in one XYHG file) with user-defined measurement density (e.g. by time interval or distance);

- wide range of radio communication of the FRSKY TARANIS Q X7 16CH 2.4GHZ transmitter, which made it possible to measure such a large object;

- the inability to preview the distribution of pickets on a current basis (checking the coverage of the water area with pickets) due to the need to mount the controller on the catamaran (the controller connects with the sonar transducer and GPS antenna via bluetooth - range up to $10 \mathrm{~m}$ ), which introduces some confusion in the profile distribution with such a large body of water;

- susceptibility of a light catamaran to water movements (waving), which causes the sonar-GNSS 
receiver axis tilt and an increase in depth indication errors, especially in the case of such deep waters; minimization of depth measurement errors in large-surface and deep reservoirs can be achieved during measurements in no wind conditions;

- susceptibility of the GNSS system to external factors (environmental, topographic), causing interruptions in the transmission of differential corrections for real-time observations and thus temporary gaps in the XYHG data recording sets;

- difficulty in keeping the course in the event of the impact of waves on the unit (frequent course correction);

- difficulty in navigating the unit in the case of long distances hydrodrone - transmitter resulting from its small size and poor visibility of the hull, which in this case is a determinant of the orientation direction for the operator;

- low power of the drive rotors and their design, which may pose a risk of immobilizing the unit flowing into the reed rush (seasonal maintenance works are carried out, including removing the rush vegetation above the water table to inhibit the process of overgrowing the reservoir in the areas of shallow waters) or blockage of the screw propellers due to screwing into the floating underwater vegetation, i.e. curly pondweed.

Regardless the relation between advantages and disadvantages, the presented measurement set is a practical tool in the hydrographic documentation of all types of water reservoirs (including anthropogenic ones), with full operator safety (remote control from the shore).

In particular, I would like to thank Mr. Marek Szmuc, the head of the Division of Mining Works in the Sulphur Mine Machów, S.A. (in liquidation) and Mr. Witold Michno for their help in my field work.

\section{REFERENCES}

Bajkiewicz-Grabowska E., (2008): Hydrologia ogólna. PWN, Warszawa.

Bąk A., (2015): Apel Sejmiku Województwa Świętokrzyskiego do Marszałka Sejmu Rzeczpospolitej Polskiej o wprowadzenie pod obrany Sejmu RP ustawy o zmianie ustawy z dnia 30 sierpnia 2013 roku o dotacji dla niektórych podmiotów. (Dz.U. z 2013r, poz. 1160).
Borowiecki A., (1994): Numeryczny model terenu $w$ aspekcie projektu i budowy obiektów inżynierskich. rozprawa nr 193, Akademia Rolnicza. Kraków.

Choiński A., (2008): Limnologia fizyczna Polski. Wydawnictwo naukowe UAM, Poznań.

Choiński A., Ptak M., (2014): Najnowsze sondowania wybranych jezior Pojezierza Wielkopolsko-Kujawskiego. Badania Fizjograficzne, Rok V - seria A - Geografia Fizyczna (A65), p. 55-63.

Cieśliński R., Ruman M., Absalon D., (2015): Wpływ czynników naturalnych i antropogenicznych na stosunki wodne wybranych jezior Słowińskiego Parku Narodowego. Monografie Komisji Hydrologicznej PTG nt. Nowoczesne metody i rozwiązania w hydrologii i gospodarce wodnej, vol. 3, p. $111-126$.

Flisiak J., Frankowski Z., Haładus A., Majer E., Kowalski M., Pietrzykowski P., Rybicki S., (2014): Rozwój i określenie przyczyn osuwiska na skarpie zbiornika wodnego po odkrywkowej kopalni siarki „Piaseczno”. Przegląd Geologiczny. vol. 62, nr 4, p. 190-215.

Gawatkiewicz R., MaciaszekJ., (1999): Profilowanie zbiorników za pomoca sondy akustycznej Ultra II. [W]: V Dni Miernictwa Górniczego i Ochrony Terenów Górniczych: Miernictwo górnicze i ochrona terenów górniczych na przełomie wieków. Materiaty konferencji naukowo-technicznej. Szczyrk, 29.09-1.10.1999 r. Prace Naukowe Głównego Instytutu Górnictwa, p. 370-381.

Gawałkiewicz R., (2017): Bagry Lake. vol. 2, History written in cartographic archives. Geoinformatica Polonica vol. 16, p. $127-138$.

Gawałkiewicz R., (2018a): Application of integration measurement technologies in inventory of Bagry water body. Geomatics and Environmental Engineering, vol. 12, no. 2, p. 33-50.

Gawałkiewicz R., (2018b): Zagrożenia zbiorników wodnych wynikające z działalności człowieka na przykładzie Stawu Plaszowskiego w Krakowie. Przegląd Geologiczny vol. 66, no. 1, p. $38-47$.

Gawałkiewicz R., (2020): Sulphur Mine "Piaseczno" - vol. 1. Historical query of 1958-2012, geology and hydrology of the mine region, reclamation. Geoinformatica Polonica vol. 19, p. 107-129.

Goluch P., Dombek A., Kapłon J., (2010): Ocena dokładności danych uzyskanych z pomiaru batymetrycznego wykonanego echosonda Lowrance LMS-527c DF iGPS. Archiwum Fotogrametrii, Kartografii i Teledetekcji, vol. 21, p. 109-118.

Goszcz A., (2001): Możliwości i ograniczenia w przywracaniu użyteczności terenom górniczym. Warsztaty $2001 \mathrm{nt}$. „Przywracanie wartości użytkowych terenom górniczym". Sympozja i konferencje - Polska Akademia Nauk - Instytut Gospodarki Surowcami Mineralnymi i Energią, nr 49, p. 95-108.

Grochowska J., Teodorowicz M., (2006): Ocena możliwości oddziaływania zlewni na jeziora Górnej Pasłęki oraz podatności tych jezior na degradację. Acta Scientiarum Polonarum. Formatio Circumiectus 5(1), p. 99-111.

Maciaszek J., (2008): Skanowanie laserowe jako nowa technologia inwentaryzacji $i$ wizualizacji zabytkowych komór 
solnych. Gospodarka Surowcami Mineralnymi, vol. 24, no. 3/2, p. 197-212.

Madusiok D., (2016): Analysis of the possibilities for reclamation after aggregate exploitation in the Cracow's quarry of Brzegi by using remote sensing and geoinformatics. Geoinformatica Polonica vol. 15, p. 113-120.

Madusiok D., (2019): The contribution to protecting the aquatic environment in open-pit aggregate mines using remote-controlled bathymetry. Geoinformatica Polonica vol. 18, p. 79-86.

OHMEX INSTRUMENTATION. Sonarmite v4.0 BTX/SPX single beam. Portable bluetooth echo sounder. Sonar Mite BTx/ SPx v4.02 2016 Lymtecvh LLC.

Olszewski P., Łączny M., (201): Sukcesja roślinna $w$ rekultywacji terenów poprzemysłowych. Przegląd Górniczy vol. 66, no. 10 , p. $110-114$.

Pawłowski S., (1956): Dokumentacja geologiczna złoża siarki w Piasecznie koło Koprzywnicy. Narodowe Archiwum Geologiczne, nr 4633/181, Warszawa.

Popielarczyk D., Templin T., (2014): Application of Integrated GNSS/Hydroacoustic Measurements and GIS Geodatabase Modelsfor Bottom Analysis of Lake Hancza: the Deepest Inland Reservoir in Poland. Pure and Applied Geophysics 171, p. 997-1011.

Szmuc M., Madej K., (2010): Likwidacja wyrobiska „Piaseczno" - budowa zbiornika wodnego. Górnictwo i Geologia, vol. 5, no. 2, Wydawnictwo Politechniki Śląskiej, Gliwice.

Szmuc M., Madej K., (2011): Była siarka! Co jest teraz?. Górnictwo i Geologia, vol 6, no. 1, Wydawnictwo Politechniki Śląskiej, Gliwice.

Sokołowski J., Socha M., Felter A., (2016): Studium możliwości występowania i wykorzystania wód leczniczych i termalnych w Tarnobrzegu wraz z określeniem uwarunkowań formalno-prawnych poszukiwania i eksploatacji wód oraz możliwości finansowania podziemnej czesści inwestycji (otworu wiertniczego), Państwowy Instytut Geologiczny - Państwowy Instytut Badawczy, Warszawa.

Staszewski R., (2014): Ta bomba może wybuchnać. Tygodnik Nadwiślański, 4 march 2015.
Sybilski D., Kraszewski C., Duszyński A., Wileński P., Pachowski J., Mirski K., (2004): Ocena $i$ badania wybranych odpadów przemystowych do wykorzystania w konstrukcjach drogowych. Instytut Badawczy Dróg i Mostów w Warszawie, Warszawa.

Szoszkiewicz K., Jusik S., Zgoła T., (2010): Klucz do oznaczania makrofitów dla potrzeb oceny stanu ekologicznego wód powierzchniowych. Inspekcja Ochrony Środowiska. Biblioteka Monitoringu Środowiska, Warszawa.

Szymczewska P., (2015): Groźne osuwiska: jak ograniczyć zniszczenia. Dziennik Polski no. 116 (21557), 20 may 2015, Kraków.

Wysocki J., Orłowski P., (2012): Analiza wpływu dokładności numerycznego modelu powierzchni terenu na obliczanie objętości mas ziemnych przy projektowaniu obiektów inżynierskich. Przegląd Naukowy Inżynieria i Kształtowanie Środowiska, no. 2 [56], Warszawa.

\section{UNPUBLISHED MATERIALS}

[1] Dodatek nr 1 do Planu Ruchu Kopalni Machów - Piaseczno na lata 1974-1975, część II - Eksploatacja piasków baranowskich dla celów Przemysłu Szklarskiego, Kopalnie i Zakłady Przetwórcze Siarki „Siarkopol” w Machowie.

[2] Sandomierskie Stowarzyszenie Rozwoju Regionalnego Lokalna Grupa Działania, Sandomierz 2007.

[3] „Dokumentacja geologiczno-inżynierska dla zabezpieczenia skarp projektowanego składowiska PIASECZNO oraz wykonania projektu technicznego obiektów w obrębie wyrobiska PIASECZNO”, Przedsiębiorstwo Geologiczne w Krakowie, Kraków 1987.

[4] Projekt techniczny prac zabezpieczających i rekultywacji wyrobiska byłej Kopalni Siarki Piaseczno - Uporządkowanie, profilowanie skarp wyrobiska i izolacja wychodni serii chemicznej - grudzień 2005 r - Przedsiębiorstwo Usługowo-Produkcyjne SIGMA BP Sp. z o.o. w Tarnobrzegu.

[5] Dyrektywa 2000/60/WE Parlamentu Europejskiego i Rady z dnia 23 października 2000 r. ustanawiająca ramy wspólnotowego działania w dziedzinie polityki wodnej. 